\title{
Range-wide Status Assessment of Cirsium longistylum (long-styled thistle)
}

Prepared for:

Burnett Land, LLC

By:

Scott Mincemoyer

Montana Natural Heritage Program

Natural Resource Information System

Montana State Library

December 2004

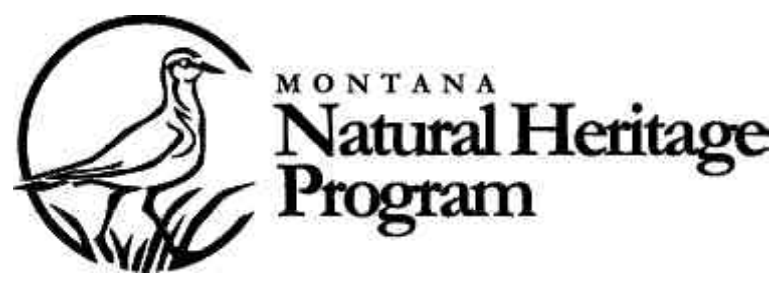




\section{Range-wide Status Assessment of Cirsium longistylum (long-styled thistle)}

Prepared for:

Burnett Land, LLC

Contract Number:

20040504

By:

Scott Mincemoyer
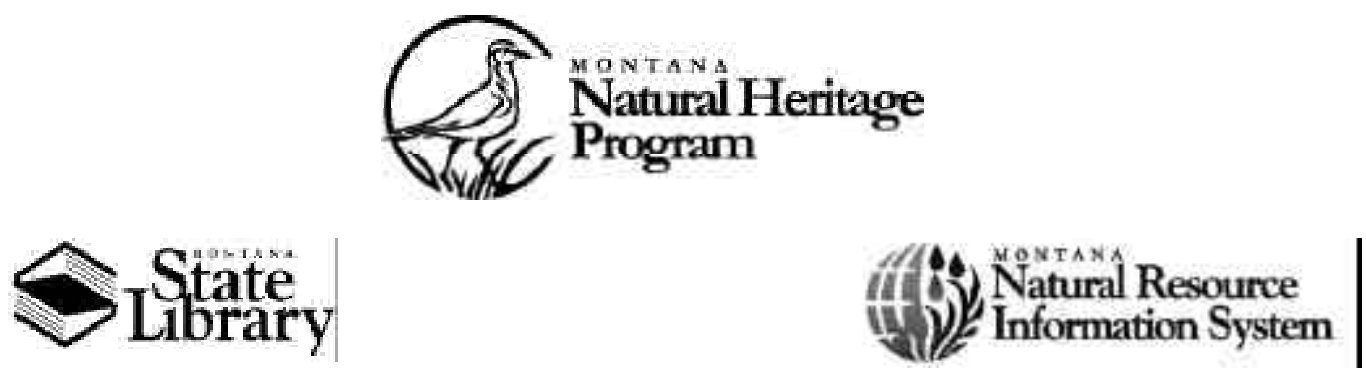

(c) 2004 Montana Natural Heritage Program

P.O. Box 201800 • 1515 East Sixth Avenue • Helena, MT 59620-1800 • 406-444-5354 
This document should be cited as follows:

Mincemoyer, S. 2004. Range-wide Status Assessment of Cirsium longistylum (long-styled thistle).

Report to Burnett Land, LLC. Montana Natural Heritage Program, Helena, MT. 22 pp. + appendices. 


\section{Executive Summary}

Cirsium longistylum Moore \& Frankton (longstyled thistle) is a state endemic thistle restricted to areas of central Montana in and around the Little Belts, Big Belts and Castle mountains, generally on sedimentary parent materials. First described as a distinct species in 1963, its overall distribution and abundance remained poorly documented for a couple decades afterwards. It is currently known from a six county area. The majority of the populations occur on National Forest lands managed by the Helena and Lewis and Clark National Forests, though a few populations occur partially or wholly on private lands.

Field surveys were initiated in 2004 to update occurrence and population data for the species. These surveys discovered several new populations, extended the boundaries of several others, failed to relocate a few occurrences and provided updated and more precise population estimates for most of the known occurrences. Additional data and field observations were collected that enabled us to clarify potential threats such as those posed by invasive weeds and an introduced bio-control Rhinocyllus conicus.

Population estimates of nearly 30,000 plants, including seven high quality populations, scattered over four mountain ranges are promising for the long-term viability of the species. Long- and short-term population trends are difficult to gauge due to the lack of good survey data over many years. However, available data and observations provide some evidence that population levels have at least remained fairly stable over the past decade, with significant yearly fluctuations possible. Threats posed by invasive weeds and the introduced bio-control provide reason for concern and population monitoring should continue in the future. As a result of this assessment, the Montana Natural Heritage Program ranking of the species will change from the current G2/S2 to G3/S3 (see Appendix A: Global/State Rank Definitions). 


\section{ACKNowledgements}

This assessment was made possible by funds from Burnett Land, LLC and the 6666 Ranch. Drake Barton conducted much of the survey work in 2004 and also in 2001 on the Helena National Forest and provided valuable background information. Thanks to Cathy Seibert at Montana State University for providing specimen information and allowing examination of herbarium specimens. Thanks to Kathy Lloyd for reviewing the document and providing many valuable insights. Coburn Currier attended to the final layout and production. Special thanks to Bryan Douglass and Bruce Goldberg for providing logistical support. Many other individuals provided useful information and help. They include Steve Shelly, Steve Cooper, Wayne Phillips and the entire staff at the Montana Natural Heritage Program. 


\section{TABLe OF Contents}

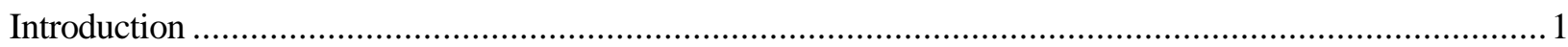

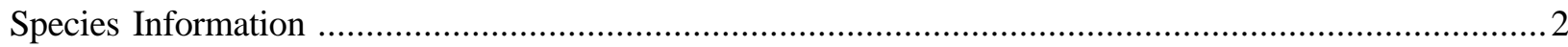

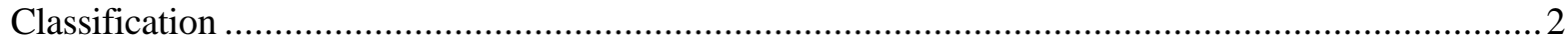

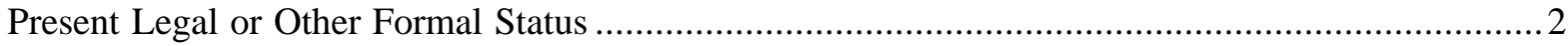

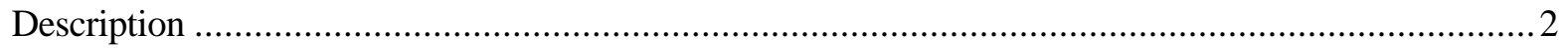

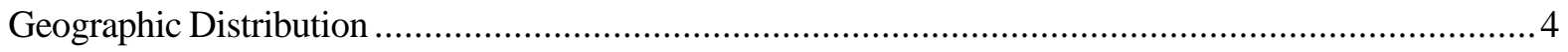

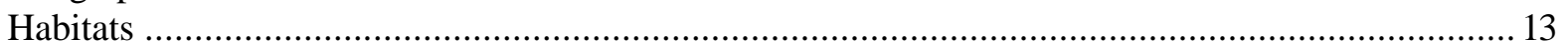

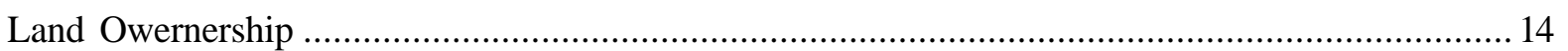

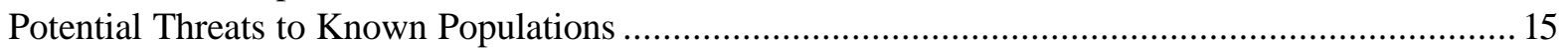

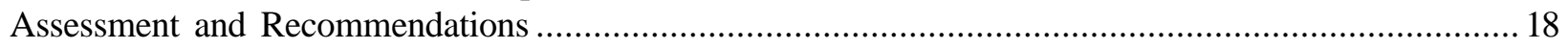

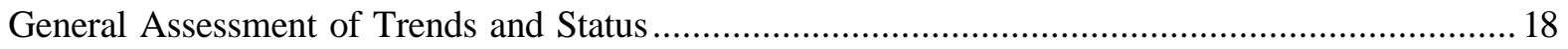

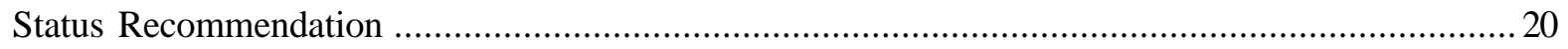

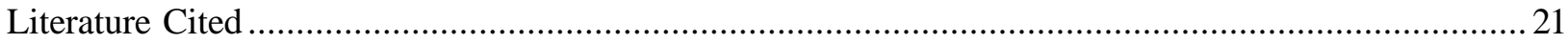

Appendix A: Global/State Rank Definitions

Appendix B: Element Occurrence Rank Definitions

Appendix C: Element Occurence Maps for Cirsium longistylum

\section{LiST OF Figures}

Figure 1. Cirsium longistylum flower head .......................................................................... 3

Figure 2. Putative hybrid between C. longistylum and C. hookerianum in the Dry Range ................... 3

Figure 3. Cirsium hookerianum flower head ........................................................................ 3

Figure 4. Occurrences of Cirsium longistylum (Extant and Historical EO's) ....................................5

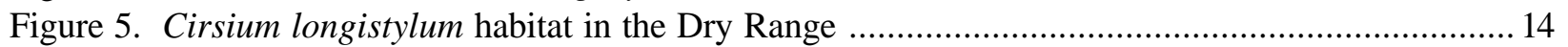

Figure 6. Cirsium longistylum habitat and flowering plants near Spur Park after fire ......................... 14

Figure 7. Rhinocyllus conicus weevils on C. longistylum in the Little Belt Mountains ....................... 15

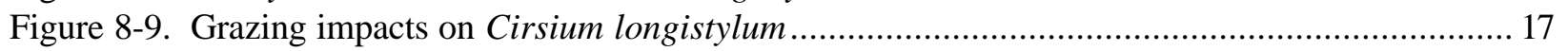

Figure 10. Permanent monitoring plot (15' radius) near Kings Hill, Little Belt Mountains ..................... 18

Figure 11. Permanent monitoring plot (37' radius) near Russian Creek, Little Belt Mountains ............... 18

Figure 12. Permanent monitoring plot (15' radius) near Neihart, Little Belt Mountains ......................... 19

\section{LIST OF TABLES}

Table 1. Element Occurrence Records for Cirsium longistylum ................................................. 8

Table 2. Ranking factors and assigned scores for the C. longistylum assessment ............................ 19 


\section{INTRODUCTION}

Cirsium longistylum Moore \& Frankton (longstyled thistle) is a state endemic thistle restricted to areas of central Montana in and around the Little Belts, Big Belts and Castle mountains, generally on sedimentary parent materials. First described as a new species in 1963 by Moore and Frankton, its overall distribution and abundance remained poorly documented for a couple decades afterwards. Starting in the 1980's the U.S. Forest Service and the Montana Natural Heritage Program (MTNHP) began to document populations of the thistle, primarily in the Little Belt Mountains. Surveys from the 1980's to 2001 substantially increased the knowledge of the distribution and abundance of the species. During this time, the documented range was extended into the Big Belts and Castle Mountains and in 2003 it was documented in the Dry Range between the Little Belts and Big Belts.
In 1990 the U.S. Fish and Wildlife Service included the species in its listing of candidate species for federal protection under the Endangered Species Act (U.S. Department of Interior 1990). After review it was determined that the species did not warrant protection under the Act. However, threats to the species from several sources and its limited distribution did raise concern about the species' long-term viability and it continued to be tracked in the state by the MTNHP. MTNHP has maintained and collected occurrence and population data on the species for several decades.

The purpose of this assessment is to collect updated survey data on the range-wide distribution and abundance of the species, identify threats, assess trends and review and update the species ranking in the state as appropriate. 


\section{Species InFormation}

\section{A. Classification}

1. Scientific Name: Cirsium longistylum Moore \& Frankton

2. Common Name: long-styled thistle, longstyle thistle

3. Family: Asteraceae (aster or sunflower family); in the tribe Cardueae

4. Type Description and Specimens Cited:

Moore, R.J. and C. Frankton. 1963.

Cytotaxonomic notes on some Cirsium species of the western United States. Canadian Journal of Botany. 41:1553-1567.

Senn, Frankton \& Gillett 5666, Aug. 23, 1951. Montana, Cascade Co., Little Belt Mountains, 3 miles SE of Monarch (Holotype: DAO)

Senn, Frankton \& Gillett 5670, Aug. 23, 1951. Montana, Meagher Co., Kings Hill, 8000 ft. (DAO) Senn 6207, Jul. 29, 1953. Montana, Meagher Co., Little Belt Mountains, 20 miles south of Neihart, Forest Green Resort, $5600 \mathrm{ft}$. (DAO)

Flodman 880, Aug. 19, 1896. Montana, Long

Baldy, Little Belt Mountains. (NY)

Herbarium reference codes are from Holmgren and Holmgren (1990).

5. Size of Genus: Cirsium is a diverse genus with 13 species in Montana (Dorn 1984, USDA NRCS 2004), approximately 101 species in the United

States (USDA NRCS 2004) and approximately 350 species worldwide (Moore and Frankton 1974).

\section{B. Present Legal or Other Formal Status}

\section{National}

a. Legal Status: The species was considered for protection under the Endangered Species Act (U.S. Department of Interior 1990) in the early 1990's but was dropped from consideration after additional survey data showed that it did not warrant protection under the Act.

\section{State}

a. Montana

i. Legal Status: None.

ii. Heritage Rank: The current (prior to this status assessment) state rank is $\mathrm{S} 2$, indicating that it is at high risk due to potentially declining population numbers and/or habitat, making it vulnerable to extinction or extirpation in the state.

\section{Description}

1. General Non-technical Description: Longstyled thistle has simple or branched stems that are $50-60 \mathrm{~cm}$ tall and up to $15 \mathrm{~mm}$ thick at the base; plants are perennial, producing daughter rosettes that live for two more years. The basal leaves are shallowly lobed, moderately spiny, green and glabrous above, and densely white-hairy below; the lower leaves are narrowly lance-shaped, up to 15 $\mathrm{cm}$ long, and lobed to $1 / 3$ or less the leaf width. The smaller upper leaves are more ovate in outline with mostly entire margins and numerous marginal spines; the herbage is covered with long, tangled, white hairs. The inflorescence usually consists of a terminal cluster of 2 to several flower heads and a number of side branches that reach up to $15 \mathrm{~cm}$ long and have fewer heads; each flower head is about $30 \mathrm{~mm}$ high, $25 \mathrm{~mm}$ wide, and subtended by a few reduced leaves. The involucral bracts occur in two main series: the outer are narrowly lanceshaped with a yellowish, dilated, and fringed apex tipped by a slender spine; the inner bracts are more lance-shaped and longer. The white disk flowers are 20-22 mm long; ray flowers are absent. There are numerous tawny bristles, which form a pappus at the tip of the achene.

2. Technical Description: Plants $50-60 \mathrm{~cm}$ high, stems thick, to $1.5 \mathrm{~cm}$ diameter at the base, ribbed, lightly arachnoid pubescent with long, multicellular hairs; perennial with biennial to perennial offsets. 
Leaves linear-lanceolate, base not decurrent, length about 10 times the width, to $15 \mathrm{~cm}$ long, $1.5 \mathrm{~cm}$ wide, lobed to $1 / 3$ width, or less, the smaller upper leaves essentially entire, lobes ovate, often irregular with numerous fine marginal spines to $5 \mathrm{~mm}$ long. Leaves gray-green, lightly arachnoid above, white, villous below. Flower heads $3 \mathrm{~cm}$ high, $2.5 \mathrm{~cm}$ wide. Arrangement of heads variable and not exclusively in a close terminal cluster, but also borne one or two at the apex of the stem and on lateral branches. Plants usually bearing many floriferous branches to $15 \mathrm{~cm}$ long on the terminal third of the stem. Heads are subtended by a few reduced leaves, the uppermost about the same size as the involucral bracts with gray multi-cellular hairs at right angles to the margin. Involucre $2 \mathrm{~cm}$ high, composed of five to six rows of phyllaries. Outer phyllaries linear-lanceolate, base 1.5-2 mm broad, weakly glandular or with a dark blotch, surface glabrous, apical portion slightly dilated with a yellow lacerate fringe, tipped by a slender $2 \mathrm{~mm}$ spine. Middle phyllaries similar but progressively less dilated-lacerate. Inner phyllaries longer, lanceolate, tip not or only slightly dilated and lacerate. Flowers white, corolla 20-22 mm long, tube 7-9 $\mathrm{mm}$, lobes $3.5-5.5 \mathrm{~mm}$, pappus $18-19 \mathrm{~mm}$, tawny with 30-40 setae, longer setae clavellate; anthers, including appendages 7.5-8.5 mm long, free anther tips usually incurved; pollen $44-51 \mu$ in outer diameter; style long exserted to $1 \mathrm{~cm}$ beyond the corolla, tip to joint of style $3.5-5 \mathrm{~mm}$. Achenes 5.5$6.5 \mathrm{~mm} \times 2 \mathrm{~mm}$, light brown, sometimes with purplish flecks. Rosette leaves moderately spiny,

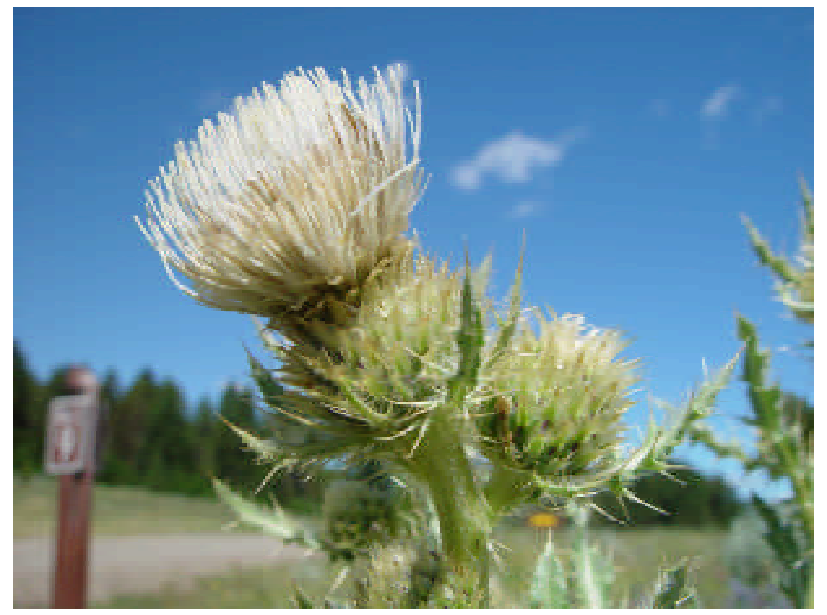

Figure 1. Cirsium longistylum flower head. Note the widened and fringed involucral bracts. the margins with broad, shallow divisions, green and glabrous above, densely white pubescent below (Moore and Frankton 1963).

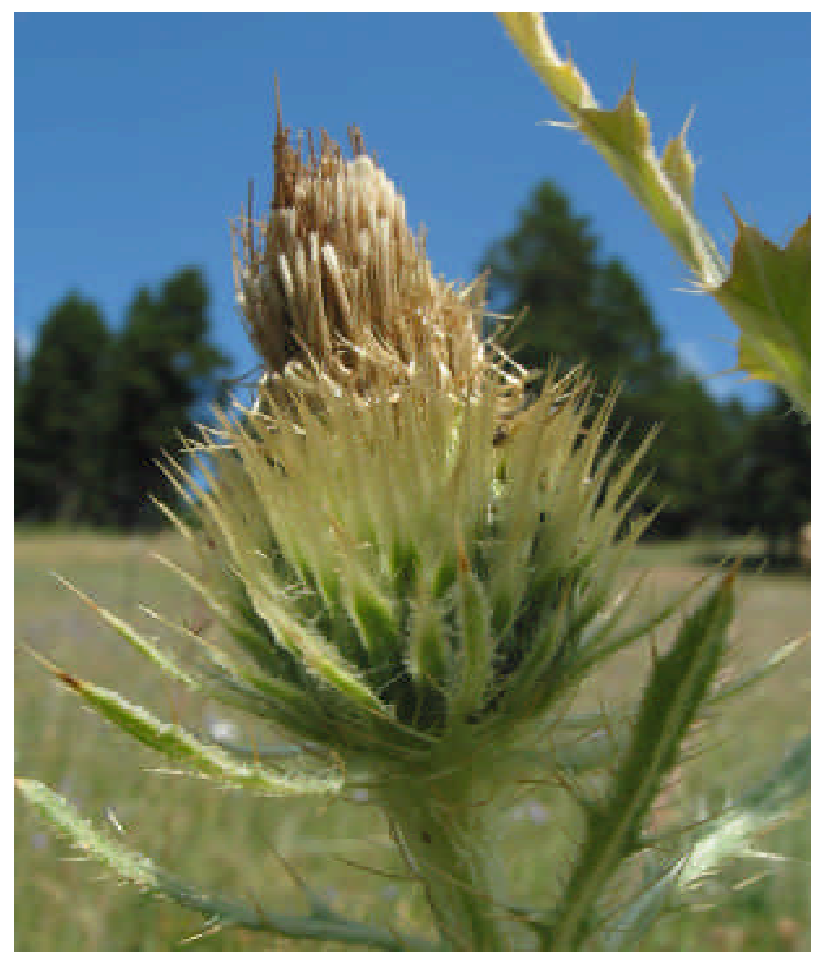

Figure 2. Putative hybrid between C. longistylum and $C$. hookerianum in the Dry Range. Note the slightly widened involucral bracts.

\section{Similar Species: Cirsium hookerianum and $C$.} scariosum are both similar to $C$. longistylum in terms of their overall morphology and biology. In addition, the geographic distribution and habitats of the species overlap. C. hookerianum can be distinguished by its long-tapering involucral bracts that are not fringed and dilated near the apex. Specimens of $C$. scariosum may be confused with

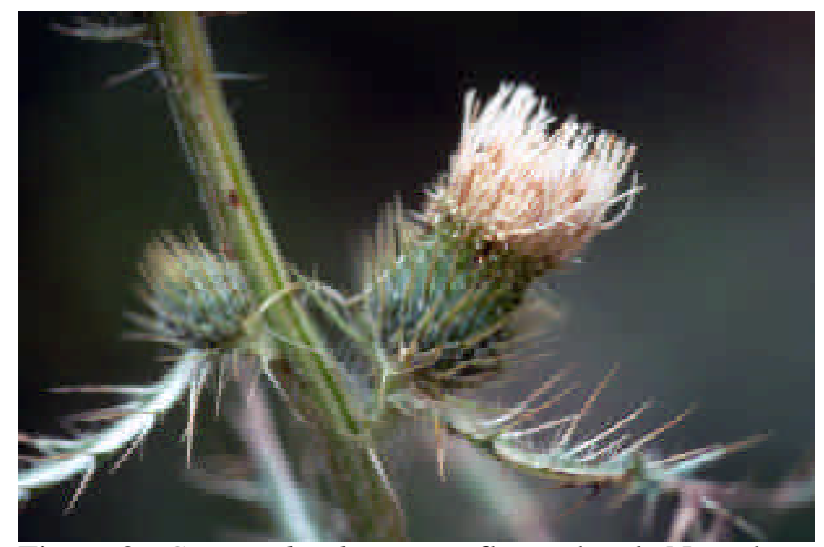

Figure 3. Cirsium hookerianum flower head. Note the long-tapering involucral bracts. 
C. longistylum in that the inner involucral bracts are sometimes fringed and dilated at the apex. However, the outer involucral bracts always taper to the tip without a fringed or dilated section. In fact, the reported occurrence of $C$. longistylum in the Elkhorn Mountains (Poole and Heidel 1993) was apparently based on specimens of $C$. scariosum with apically fringed and dilated inner involucral bracts intermixed with $C$. hookerianum (Mincemoyer 2004). Confusion among the taxa arises due to apparent hybridization and introgression among the species which results in intermediate bract characteristics. Currently, identification of rosettes and vegetative specimens based on morphological characters alone cannot be reliably determined.

\section{Phylogenetic Relationships: Cirsium}

longistylum is closely related to other members of the genus, such as $C$. hookerianum and $C$. scariosum. Chromosome counts of the 3 species are all 2n=34 (Mathews 1980, Moore and Frankton 1963, Ownbey and Hsi 1963, Gardner 1974). Results of a genetic analysis by Brunsfeld and Baldwin (1994) provided additional evidence that $C$. longistylum is a distinct species and actually appears to be the most genetically distinct of the 3 species studied in west-central Montana. However, C. longistylum appears to commonly hybridize with the former and probably the latter as well. Based on bract morphology, putative hybrids with $C$. hookerianum appear to be common in areas where the two species are in close proximity, though enzyme electrophoresis found that the putative hybrids were most closely related to "pure" C. longistylum (Brunsfeld and Baldwin 1994). Also of interest is the fact that samples of $C$. hookerianum and C. scariosum taken from outside Montana were genetically distant from samples of the same species taken from within the state, based on an analysis of randomly amplified polymorphic DNA (RAPD) (Brunsfeld and Baldwin 1994). This suggests that introgression among the species may have historically occurred in the region and that gene flow among the species is likely still taking place.

\section{Geographic Distribution}

\section{Range: C. longistylum is a state endemic} thistle restricted to areas of central Montana in and around the Little Belts, Big Belts and Castle mountains, generally on sedimentary parent materials. Currently, the known distribution of the species is centered in the Little Belt Mountains, with additional populations in the Big Belts, Castle Mountains and the Dry Range. Populations also occur in the valley between the Little Belts and the Castle Mountains. The first known collection of the species was by Flodman in 1896 in the Little Belt Mountains. However, the plant was not formally described and recognized as a new species until 1963 (Moore and Frankton 1963) so the species went largely un-noticed for another 70 years after its first known collection. The species was known only from the Little Belts until 1976 when it was collected in the Big Belts by Robert Dorn (specimen deposited at MONT), though further surveys in the Big Belts did not take place until 1983. Its range was further extended into the Castle Mountains with a collection by Dana Field in 1991 and subsequent field surveys in 1992. Finally, in 2003 it was documented in the Dry Range between the Big Belts and the Little Belts (Olsen 2003). This brings the current known range to six counties, not including a historical collection from the Big Snowies. 


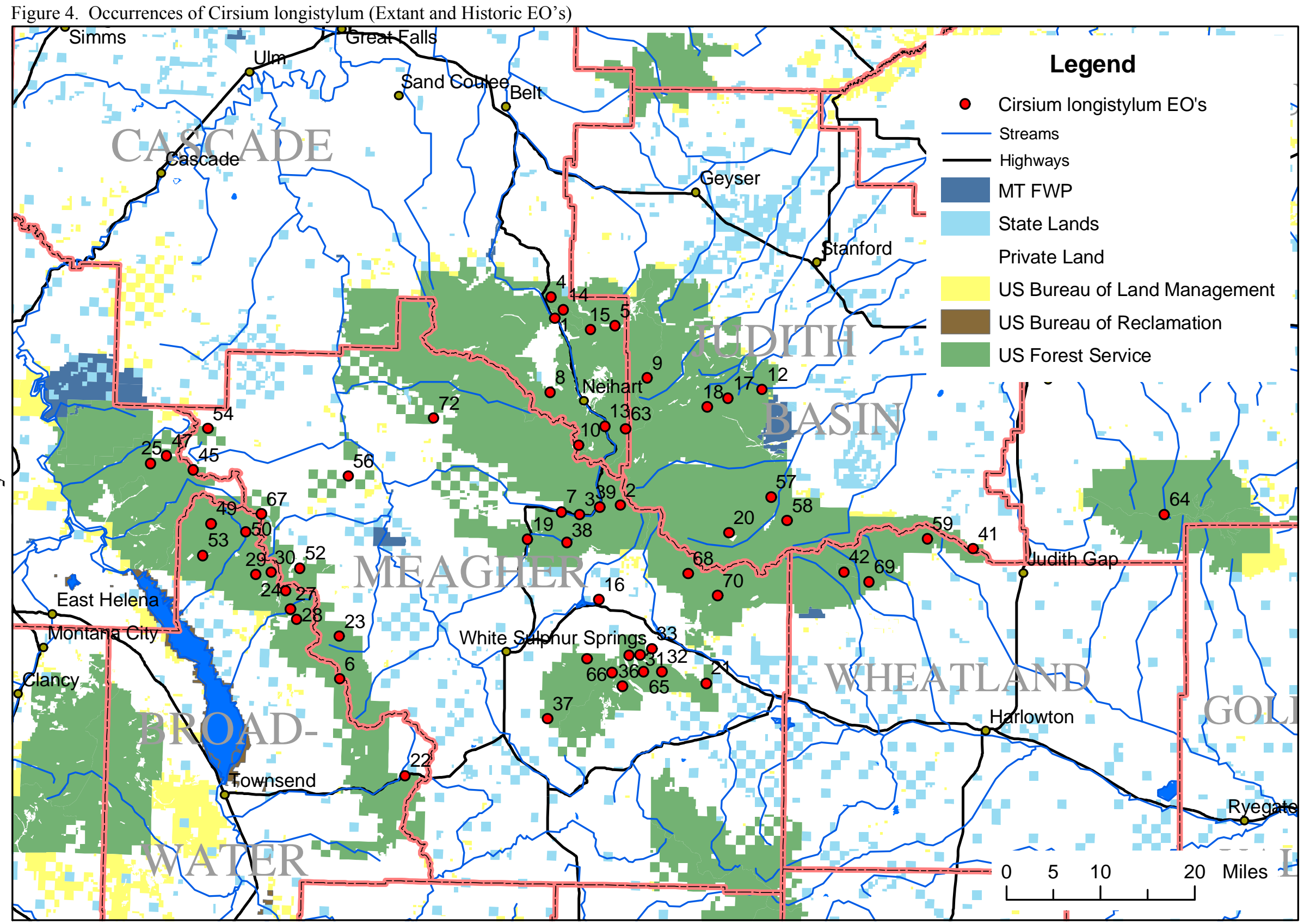


2. Historical Populations: A survey of the Montana State University Herbarium (MONT) in 2004 located one specimen from the Big Snowy Mountains:

Booth 60121. July 19, 1960. Fergus Co., Snowy Mtns., about 20 miles south of Lewistown.

This specimen appears to be "pure" $C$. longistylum or a putative hybrid leaning towards $C$.

longistylum. Limited surveys in the Big Snowy

Mountains in August and September of 2004 could not relocate this population or any $C$. longistylum in the area. Unfortunately, the label information with this specimen is vague in regards to the collection locality and population size. The only native thistle species observed in the range was $C$. eatonii (Gray) Robins., which was locally abundant from lower elevation dry streambeds to the crest of the range. The geology and habitats found in the Big Snowies appear suitable for supporting populations of $C$. longistylum and additional future surveys may document the species in the area.

Data for five additional historical occurrences or populations that could not be relocated in 2004 are also maintained by the Montana Natural Heritage Program. These occurrences are described in Table 1.

Past reports of the species from the Elkhorn Mountains (Poole and Heidel 1993) appear to be in error and were based on mis-identification of $C$. scariosum. Field surveys to the site in 2004 by Mincemoyer were unable to locate any $C$. longistylum in the area, however the site does support a large population of $C$. hookerianum with minor amounts of $C$. scariosum. This is actually supported by the data collected in 1992 that states "Only 1 plant, in fruit, with $C$. longistylum characters was observed among a population of approximately 100 plants of $C$. hookerianum and possible hybrids and backcrosses." The specimens of $C$. scariosum examined at the site generally have inner involucral bracts dilated and fringed at the apex with outer bracts tapered to the tip. This probably led to the confusion in the identification of the species. In addition, the parent material of the site is generally granitics, while $C$. longistylum is typically found on calcareous substrates.

\section{Additional Survey Areas: Mapping of suitable} habitat for $C$. longistylum using ArcGIS and layers of geology, soils and precipitation was done to identify potential survey areas for 2004. Preliminary mapping identified several suitable areas in the Big Snowies, Elkhorns and Judith mountains, in addition to the mountain ranges already known to support populations of $C$. longistylum. Field surveys to several of the areas in the Elkhorn Mountains with potential suitable habitat failed to find any $C$. longistylum. However, the native thistles $C$. hookerianum and $C$. scariosum were encountered. Limited surveys in the Judith Mountains also failed to locate any $C$. longistylum. Other areas that have been surveyed in past years without any success include the Highwood Mountains and areas near Homestake Pass west of Helena.

\section{Extant Sites: Occurrences of C. longistylum} are summarized in Table 1 and Figure 4. Detailed occurrence maps are provided in Appendix C. The seven largest and highest quality (A or $\mathrm{AB}$ ranked) populations are described in further detail below.

The Kings Hill (EO \#2) site was first observed in 1951, though details of the population were not documented until 1986. This is the largest known occurrence with 2004 surveys estimating the population at $9500+$ individuals. This population extends across approximately 2000 acres on elevations of 6400-8100 feet. Populations extend from Kings Hill Pass and Showdown Ski area east and southeast to the Spur Park and Ant Park areas and south along portions of Deadman Creek. Habitats include subalpine and montane meadows, open subalpine forests and roadsides. In the Ant Park area, the thistle responded positively to a previous fire with many flowering individuals visible from the road in 2004. Very few weeds are currently present in this population though minor amounts of Cirsium arvense (Canada thistle), Cynoglossum officinale (houndstongue) and Phleum pratense (common timothy) were noted in 2004. Dominant vegetation is variable across the 
area but includes species such as Festuca idahoensis (Idaho fescue), Potentilla fruticosa (shrubby cinquefoil), Danthonia intermedia (intermediate oatgrass), Stipa nelsonii (Nelson's needlegrass) and Potentilla gracilis (slender cinquefoil). Small numbers of $C$. hookerianum and putative hybrids were noted in the area, though overall this population appears to be mostly "pure" C. longistylum. A large population of $C$. hookerianum occurs several miles to the west in the Moose Park and O'Brien Park areas and it seems likely that gene flow between these two populations is occurring.

The Duck Creek Pass (EO \#6) site in the Big Belt Mountains was estimated at 1200 plants during a 2004 survey. Previous estimates of population size were imprecise, with a 1992 survey placing the population between 1000-5000 individuals. The population covers approximately 200 acres and extends from near Gypsy Lake to approximately 2 miles west of Duck Creek Pass with the largest concentration of plants near the pass. The best and most intact habitat for the species occurs in the subalpine and montane meadows near the pass and immediately to the west. Several non-native species are present at the site, particularly at lower elevations. Phleum pratense is abundant while Agrostis stolonifera (bentgrass) and Bromus inermis (smooth brome) are locally common. Also present in the area are Cirsium arvense, Cirsium vulgare (bull thistle) and Carduus nutans (musk thistle). In spite of the threats posed by non-native species at the site, this is the most intact population within the Big Belt Mountains.

The Russian Flat (EO \#20) site is the second largest population in the Little Belt Mountains with an estimate of 2000 individuals in 2004 over an area of about 700 acres. This population was first observed in 1990 with survey information noting "thousands of plants" in the area. Plants are concentrated in the meadows of Russian Flat, along Russian Creek and in meadows west of Russian Creek and south of Forest Service Road 487. However, individual plants are scattered along the road from approximately 2 miles east of Russian Flat to Hoover Spring along the South Fork Judith River about 6 miles west of Russian Flat. Though native vegetation dominates the area, several nonnative species occur throughout the area, including Phleum pratense, Cirsium vulgare, Bromus inermis, Cynoglossum officinale and Carduus nutans.

The Atlanta Creek (EO \#23) population occurs in the central Big Belts with an estimated population of 1000 individuals in 2004. The population occurs along Atlanta Creek and the open ridge to the north in section 6 at elevations of 6400-7400 feet. This area was first surveyed in 1992 and the population was documented at 250-400 plants over a 40 acre area. Of the 7 largest populations described here in detail this one may have the highest population density of $C$. longistylum. Putative hybrids occur at the site, though only account for approximately $15 \%$ of the Cirsium plants in the area. The site is dominated by native vegetation with small amounts of Bromus inermis and Phleum pratense.

The Dry Range (EO \#56) population is a new site first documented in 2003 in montane meadows and open forests from 5000-6200 feet elevation. The site is approximately 20 miles northwest of White Sulphur Springs and occurs on a mix of private and National Forest lands. Surveys in 2004 estimated the population at approximately 2200 plants, along with numerous putative hybrids with Cirsium hookerianum. Density of C. longistylum tends to be highest near the crest of the range and on upper, south-facing slopes and declines quickly with decreasing elevation. The 2004 survey mapped occupied areas totaling approximately 790 acres. The 2003 estimate of 10,000 plants was too high due to inclusion of unsuitable habitat and putative hybrids. This population occurs in high quality montane meadows dominated by Stipa richardsonii, (Richardson's needlegrass) Festuca scabrella (rough fescue) and Festuca idahoensis with a diverse and abundant forb component. Several non-native species occur throughout the survey area with Bromus inermis and Phleum pratense being locally abundant in several disturbed meadows. The introduced bio-control agent Rhinocyllus conicus was observed in approximately $80 \%$ of the flower heads that were examined, with significant reductions in mature seeds. However, later developing flower heads 
were largely uninfested since their development did not coincide with of the development of the weevil.

The East Fork Checkerboard Creek (EO \#36) site is the largest documented population in the Castle Mountains with an estimated 1200 plants. $C$. longistylum was first observed in the area in 1992. The currently documented population extends from the headwaters of the East Fork Checkerboard Creek along FS Road 211, southeast along the South Fork Bonanza Creek and FS Road 581, north along Limestone Ridge and to the east along FS Road 585. Occupied habitats include riparian grasslands, montane meadows and several miles of roadsides at elevations of 6500-7000 feet. The area occupied by this population is approximately 80 acres. Species composition varies across the population, though dominants include Festuca idahoensis, Poa pratensis and Koeleria macrantha (prairie junegrass). Non-natives in the area include Cirsium arvense, Cynoglossum officinale, and Bromus inermis.
The Forest Service Road 274 (EO \#68) population is a new occurrence documented in 2004. It occurs in the Little Belt Mountains and extends from Elephant Rock north for approximately 7 miles. Another significant subpopulation occurs in Bear Park about 3 miles north-northeast of Elephant Rock. Surveys in 2004 documented a population between 1000-1200 plants covering an area of almost 250 acres. The majority of the population occurs adjacent to roads, though significant numbers of plants occur in montane meadows dominated by Festuca scabrella, Festuca idahoensis, Koeleria macrantha, Geranium viscosissimum (sticky geranium), Artemisia tridentata (big sagebrush) and Potentilla gracilis. Exotic species associated with this occurrence include Bromus inermis, Cirsium arvense and Phleum pratense.

Table 1. Element Occurrence Records for Cirsium longistylum. See Appendix B for a description of the ranking codes.

\begin{tabular}{|c|c|c|c|c|c|}
\hline EO \# & County & Survey Site & Survey Data & Description & Ranking \\
\hline 01 & Cascade & $\begin{array}{l}\text { Monarch SE. Approximately } 3 \\
\text { miles SE of Monarch. }\end{array}$ & $\begin{array}{l}\text { No population data. Type locality, } \\
\text { collected in 1951. Last observation in } \\
1983 \text {. }\end{array}$ & $4820-4920 \mathrm{ft}$. & $\mathrm{H}$ \\
\hline 02 & $\begin{array}{l}\text { Cascade, } \\
\text { Meagher, } \\
\text { Judith Basin }\end{array}$ & $\begin{array}{l}\text { Kings Hill. Little Belt Mountains, } \\
\text { King's Hill Pass and Showdown } \\
\text { Ski area east and southeast to the } \\
\text { Spur Park and Ant Park areas and } \\
\text { south along portions of Deadman } \\
\text { Creek. }\end{array}$ & $\begin{array}{l}\text { 2004: } 3 \text { large subpops. surveyed: with } \\
\text { approx 9,500 plants. 1992: About } \\
2200 \text { plants in } 2 \text { surveyed subpops., } \\
\text { concentrated around Kings Hill. None } \\
\text { in campground, few along road or in } \\
\text { ski area. 1990: Extended population } \\
\text { boundaries, tens of thousands of } \\
\text { plants. 1986: Frequent. }\end{array}$ & $\begin{array}{l}\text { 6400-8100 ft. } \\
\text { Roadsides, } \\
\text { meadows. }\end{array}$ & $\mathrm{A}$ \\
\hline 03 & Meagher & $\begin{array}{l}\text { Forest Green. About } 16 \text { miles } \\
\text { south of Neihart. }\end{array}$ & $\begin{array}{l}1992 \text { survey estimated } 100 \text { Cirsium } \\
\text { plants with <10\% showing } \\
\text { characteristics of } C \text {. longistylum. First } \\
\text { observation in } 1953 \text {. }\end{array}$ & $\begin{array}{l}\text { 6030-6040 ft. } \\
\text { Meadow. }\end{array}$ & $\mathrm{C}$ \\
\hline 04 & Cascade & $\begin{array}{l}\text { Monarch. Approximately } 1 \text { mile } \\
\text { east of Hwy. } 89 \text { on Dry Fork Road } \\
(\# 120) .\end{array}$ & $\begin{array}{l}\text { 2004: } 0 \text { plants. 1992: } 0 \text { plants. } 1986: 2 \\
\text { plants observed. }\end{array}$ & $\begin{array}{c}4822 \mathrm{ft} . \\
\text { Roadsides, } \\
\text { disturbed } \\
\text { grasslands. }\end{array}$ & F \\
\hline 05 & Cascade & $\begin{array}{l}\text { Bender Creek Trail. Little Belt } \\
\text { Mountains, } 9.7 \text { miles east of } \\
\text { Monarch on FS Road \#120 (Dry } \\
\text { Fork Belt Creek Road); population } \\
\text { is at junction of road with trail } \\
\# 318 \text { (Bender Creek Trail). }\end{array}$ & $\begin{array}{l}\text { 2004: Resurvey of the site found no } C \text {. } \\
\text { longistylum. C. hookerianum and } \\
\text { hybrids present. } 1994:>100 \text { flowering } \\
\text { plants \& rosettes. 1992: } 23 \text { plants, } 18 \\
\text { flowering, } 3 \text { of which were } C \text {. } \\
\text { longistylum. 1990: } 10 \text { plants counted. } \\
\text { 1986: } 20 \text { plants; evidence of possible } \\
\text { hybridization with } C \text {. hookerianum. }\end{array}$ & $\begin{array}{l}4680-5360 \mathrm{ft} . \\
\text { Meadows, } \\
\text { roadsides, } \\
\text { riparian areas, } \\
\text { disturbed sites. }\end{array}$ & $\mathrm{F}$ \\
\hline
\end{tabular}


Table 1. Continued.

\begin{tabular}{|c|c|c|c|c|c|}
\hline EO \# & County & Survey Site & \begin{tabular}{|c|} 
Survey Data \\
\end{tabular} & Description & Ranking \\
\hline 06 & $\begin{array}{l}\text { Broadwater, } \\
\text { Meagher }\end{array}$ & $\begin{array}{l}\text { Duck Creek Pass. Big Belt } \\
\text { Mountains, Duck Creek Pass Road } \\
\# 139 \text {, beginning just west of turnoff } \\
\text { to Thompson Gulch guard station } \\
\text { and Gipsy Lake area, and scattered } \\
\text { along road to area west of Duck } \\
\text { Creek Pass. }\end{array}$ & $\begin{array}{l}\text { 2004: } 1200 \text { plants. Hybrids with } C \text {. } \\
\text { hookerianum appear common } \\
\text { especially the further one goes from } \\
\text { the pass. Previous population } \\
\text { estimates are vague. } 2001 \text { : Common } \\
\text { in area. 1992: } 1000-5000 \text { individuals, } \\
\text { all in flower. 1983: Some } \\
\text { subpopulations have >100 plants; } \\
\text { another thistle, possibly } C \text {. } \\
\text { hookerianum, occurs in all areas, } \\
\text { probably hybridizing. }\end{array}$ & $\begin{array}{l}\text { 6320-7600 ft. } \\
\text { Roadsides, } \\
\text { meadows. }\end{array}$ & $\mathrm{A}$ \\
\hline 07 & Meagher & $\begin{array}{l}\text { Jumping Creek Campground. } \\
\text { Jumping Creek Campground \& } \\
\text { access road, about } 17.5 \text { miles south } \\
\text { of Neihart off U.S. Hwy } 89 .\end{array}$ & $\begin{array}{l}\text { 2004: Approx. } 120 \text { plants. } 1992: \\
\text { Approx. } 75 \text { plants, estimate } 75 \% \text { are } \\
\text { C. longistylum. }\end{array}$ & $\begin{array}{l}5850-6240 \mathrm{ft} . \\
\text { Meadows, } \\
\text { roadsides, open } \\
\text { forest. } \\
\end{array}$ & $\mathrm{C}$ \\
\hline 08 & Cascade & $\begin{array}{l}\text { Neihart. Just north of Neihart, } \\
\text { along FS Road \#834 that extends } \\
\text { west up Harley Creek and north to } \\
\text { upland meadows. }\end{array}$ & $\begin{array}{l}\text { 2004: Approx } 25 \text { C.longistylum plants } \\
\text { among 600-800 plants of } C \text {. } \\
\text { hookerianum. 1992: About } 1,000 \\
\text { Cirsium plants only } 1 \% \text { are } C \text {. } \\
\text { longistylum. 1990: Frequent in moist } \\
\text { streamside habitats and moist } \\
\text { meadows of upland areas. }\end{array}$ & $\begin{array}{l}5440-7040 \mathrm{ft} . \\
\text { Roadsides, } \\
\text { meadows, } \\
\text { riparian areas. }\end{array}$ & $\mathrm{D}$ \\
\hline 09 & $\begin{array}{c}\text { Cascade, } \\
\text { Judith Basin }\end{array}$ & $\begin{array}{l}\text { Long Baldy. Long Baldy, Little } \\
\text { Belt Mountains. }\end{array}$ & Historical record from 1896. & $-\overline{--}$ & $\mathrm{H}$ \\
\hline 10 & $\begin{array}{l}\text { Meagher, } \\
\text { Cascade }\end{array}$ & $\begin{array}{l}\text { O'Brien Creek. Little Belt } \\
\text { Mountains, west of Kings Hill } \\
\text { along FS Road \#839 from O'Brien } \\
\text { Park to Lone Tree Park. }\end{array}$ & $\begin{array}{l}\text { 2004: Estimate } 50-100 \text { C. longistylum } \\
\text { plants mixed in with several thousand } \\
\text { C. hookerianum and hybrids. 1992: } \\
\text { over 3,000 C. hookerianum in Moose } \\
\text { Park, C. longistylum found only along } \\
\text { roads. }\end{array}$ & $\begin{array}{l}7200-7300 \mathrm{ft} . \\
\text { Meadows, open } \\
\text { forest, } \\
\text { roadsides. }\end{array}$ & $\mathrm{C}$ \\
\hline 12 & Judith Basin & $\begin{array}{l}\text { Hay Coulee. Little Belt } \\
\text { Mountains, south of Sage Creek up } \\
\text { Hay Coulee, about } 15 \text { miles west of } \\
\text { Utica. }\end{array}$ & $\begin{array}{l}\text { 2004: Estimate } 220 \text { C. longistylum } \\
\text { plants within a larger population of } C \text {. } \\
\text { hookerianum and hybrids. 1992: } \\
\text { Frequent. }\end{array}$ & $\begin{array}{l}5440-6180 \mathrm{ft} . \\
\text { Meadow. }\end{array}$ & B \\
\hline 13 & Cascade & $\begin{array}{l}\text { Belt Creek: Little Belt Mountains, } \\
\text { Belt Creek, along U.S. Hwy } 89,1 \\
\text { mile south of Jefferson Creek, } \\
\text { about } 4 \text { miles southeast of Neihart. }\end{array}$ & $\begin{array}{l}\text { 2004: Approx. } 200 \text { Cirsium plants } \\
\text { observed, about } 75 \text { C. longistylum and } \\
\text { the rest } C \text {. hookerianum and hybrids. } \\
\text { 1992: About } 50 \text { plants scattered along } \\
\text { creek \& highway for } 2 \text { miles either } \\
\text { side of Many Pines Campground. } \\
\text { 1986: } 170 \text { plants counted, } 85 \text { on each } \\
\text { side of the creek; of } 41 \text { plants studied, } \\
24 \text { were identified as } \text { C. longistylum } \\
\text { and } 4 \text { as } C \text {. hookerianum; } 13 \\
\text { displayed characteristics intermediate } \\
\text { between the two. }\end{array}$ & $\begin{array}{l}6080 \mathrm{ft} . \\
\text { Riparian areas, } \\
\text { roadsides. }\end{array}$ & $\mathrm{C}$ \\
\hline 14 & Cascade & $\begin{array}{l}\text { Paine Gulch. Little Belt } \\
\text { Mountains, Paine Gulch, } \\
\text { approximately } 1.5-2.2 \text { miles } \\
\text { upstream from confluence with } \\
\text { Belt Creek. }\end{array}$ & 1987: 11-50 plants observed. & $\begin{array}{l}\text { 5200-5400 ft. } \\
\text { Disturbed } \\
\text { meadow. }\end{array}$ & $\mathrm{U}$ \\
\hline 15 & Cascade & $\begin{array}{l}\text { Servoss Mountain. Little Belt } \\
\text { Mountains, southeast side of } \\
\text { Servoss Mountain, north of divide } \\
\text { between Ruby Creek and Henn } \\
\text { Gulch. }\end{array}$ & A single observation from 1987. & $\begin{array}{c}6400 \mathrm{ft} . \\
\text { Motorized trail. }\end{array}$ & $\mathrm{U}$ \\
\hline 16 & Meagher & $\begin{array}{l}\text { Bair Ranch. From Lake Sutherlin; } \\
\text { about } 7 \text { miles NE of White Sulphur } \\
\text { Springs to Bair Reservoir mainly } \\
\text { on the Bair Ranch. }\end{array}$ & $\begin{array}{l}\text { 2004: Survey of Bair Ranch and Lake } \\
\text { Sutherlin area estimated } 600 \text { C. } \\
\text { longistylum with numerous hybrids, } \\
\text { C. hookerianum, and C. scariosum. } \\
\text { First observation in } 1986 \text {. }\end{array}$ & $\begin{array}{l}5500-5700 \mathrm{ft} . \\
\text { Meadow. }\end{array}$ & $\mathrm{BC}$ \\
\hline 17 & Judith Basin & $\begin{array}{l}\text { Upper Bear Gulch. Little Belt } \\
\text { Mountains, upper Bear Gulch, } \\
\text { about } 20 \text { miles west of Utica. }\end{array}$ & $\begin{array}{l}\text { 2004: Approx. } 300 \text { C. longistylum } \\
\text { plants mixed in with another } 300 \text { C. } \\
\text { hookerianum and hybrids. } 1990: \\
\text { About } 100 \text { plants. }\end{array}$ & $\begin{array}{l}6200-6530 \mathrm{ft} . \\
\text { Meadow, } \\
\text { riparian area. }\end{array}$ & $\mathrm{C}$ \\
\hline
\end{tabular}




\begin{tabular}{|c|c|c|c|c|c|}
\hline EO \# & County & Survey Site & Survey Data & Description & Ranking \\
\hline 18 & Judith Basin & $\begin{array}{l}\text { Skunk Gulch. Little belt } \\
\text { Mountains, Skunk Gulch, about } 12 \\
\text { miles northeast of Sapphire } \\
\text { Village. }\end{array}$ & $\begin{array}{l}\text { 2004: Approx. } 1000 \text { C. longistylum } \\
\text { plants in a larger population } \\
\text { containing C. hookerianum and } \\
\text { hybrids. 1990: Several hundred plants } \\
\text { in flower. }\end{array}$ & $\begin{array}{l}6280-6530 \mathrm{ft} . \\
\text { Meadow, } \\
\text { riparian area. }\end{array}$ & $\mathrm{B}$ \\
\hline 19 & Meagher & $\begin{array}{l}\text { Thornquist Gulch. Little Belt } \\
\text { Mountains. From White Sulphur } \\
\text { Springs take U.S. Highway } 89 \\
\text { north about } 15 \text { miles, then FS Road } \\
\text { \#831 north about } 0.5 \text { mile. } \\
\text { Population extends } 0.5-1.0 \text { mile } \\
\text { along Thornquist Gulch and along } \\
\text { Miller Gulch. }\end{array}$ & $\begin{array}{l}\text { 2004: Approx. } 180 \text { C. longistylum } \\
\text { plants found in a mix of hybrids and } \\
\text { C. hookerianum. } 1992 \text { : About } 50 \\
\text { plants. 1990: About } 50 \text { plants. }\end{array}$ & $\begin{array}{l}5680-5840 \mathrm{ft} . \\
\text { Roadsides, } \\
\text { riparian areas, } \\
\text { open forest. }\end{array}$ & $\mathrm{C}$ \\
\hline 20 & Judith Basin & $\begin{array}{l}\text { Russian Flat. Little Belt } \\
\text { Mountains, Russian Creek, about } \\
18 \text { miles west of Sapphire Village } \\
\text { and along the South Fork Judith } \\
\text { River. }\end{array}$ & $\begin{array}{l}\text { 2004: Approx } 2000 \text { plants. 1992: } \\
\text { About } 600 \text { individuals, approx. } 80 \% \\
\text { C. longistylum. } 1990 \text { : Thousands of } \\
\text { plants plus scattered individuals } \\
\text { extending to the east and west about } 1 \\
\text { mile. }\end{array}$ & $\begin{array}{l}\text { 6350-6640 ft. } \\
\text { Meadow. }\end{array}$ & $\bar{A}$ \\
\hline 21 & Meagher & $\begin{array}{l}\text { Pasture Gulch. Take U.S. } \\
\text { Highway } 12 \text { about } 5 \text { miles east of } \\
\text { Checkerboard, then go south on FS } \\
\text { Road \#694 about } 4 \text { miles into } \\
\text { Pasture Gulch. }\end{array}$ & $\begin{array}{l}\text { 2004: Approx. } 180 \text { plants. 1992: } 50 \\
\text { plants. 1991: 50-100 plants scattered } \\
\text { along road and in recently logged } \\
\text { areas. }\end{array}$ & $\begin{array}{l}5300-5640 \mathrm{ft} . \\
\text { Roadsides, } \\
\text { partially logged } \\
\text { slopes. }\end{array}$ & $\mathrm{D}$ \\
\hline 22 & Broadwater & $\begin{array}{l}\text { Carl Creek. Big Belt Mountains, } \\
\text { along Carl Creek trail, just south of } \\
\text { trailhead off Highway } 12 .\end{array}$ & 2004: 12 plants. $1992: 7$ plants total. & $\begin{array}{l}5440-5480 \mathrm{ft} . \\
\text { Riparian areas, } \\
\text { roadsides. }\end{array}$ & $\mathrm{CD}$ \\
\hline 23 & Meagher & $\begin{array}{l}\text { Atlanta Creek. Big Belt } \\
\text { Mountains. Atlanta Ridge above } \\
\text { Atlanta Creek, west of Atlanta } \\
\text { Road \#575, upper end of ridge and } \\
\text { along Atlanta Creek. }\end{array}$ & $\begin{array}{l}\text { 2004: Estimate of } 1000 \text { plants with } \\
\text { hybrids and C. hookerianum also } \\
\text { present. 1992: Estimate of } 250+\text { plants } \\
\text { in peak flower, the majority at west } \\
\text { end of meadow. }\end{array}$ & $\begin{array}{l}\text { 6400-7440 ft. } \\
\text { Meadows, open } \\
\text { forest, riparian } \\
\text { areas. }\end{array}$ & $\bar{A}$ \\
\hline 24 & Broadwater & $\begin{array}{l}\text { Cement Gulch. Big Belt } \\
\text { Mountains; take County Road } 287 \\
\text { up Confederate and Cement } \\
\text { gulches to near Ready Cash Gulch. }\end{array}$ & $2001: 25$ to 50 plants. & $\begin{array}{l}5600-6100 \mathrm{ft} . \\
\text { Riparian areas. }\end{array}$ & $\mathrm{C}$ \\
\hline 25 & $\begin{array}{l}\text { Lewis \& } \\
\text { Clark }\end{array}$ & $\begin{array}{l}\text { Hogback Mountain. Big Belt } \\
\text { Mountains; fellfield on top of } \\
\text { Hogback Mountain. }\end{array}$ & Observation from 1992. & $\begin{array}{l}7580-7800 \mathrm{ft} . \\
\text { Fellfield. }\end{array}$ & $\bar{U}$ \\
\hline 27 & Broadwater & $\begin{array}{l}\text { Confederate Gulch. Big Belt } \\
\text { Mountains, along Confederate } \\
\text { Gulch just above Cement Gulch. }\end{array}$ & $\begin{array}{l}\text { 2004: Estimate of } 35 \text { plants. 2001: No } \\
\text { plants located. First observation in } \\
1992 .\end{array}$ & $\begin{array}{l}5220-5300 \mathrm{ft} . \\
\text { Disturbed area. }\end{array}$ & $\mathrm{C}$ \\
\hline 28 & Broadwater & $\begin{array}{l}\text { Boulder Creek. Big Belt } \\
\text { Mountains, ridgeline above } \\
\text { Boulder Creek, accessible from FS } \\
\text { Road \#4171 to logging road to FS } \\
\text { Trail \#142, which cuts over the } \\
\text { ridge. }\end{array}$ & $\begin{array}{l}\text { 1992: } 20-40 \text { plants widely scattered } \\
\text { across exposed slope. }\end{array}$ & $\begin{array}{l}\text { 6920-7020 ft. } \\
\text { Meadow. }\end{array}$ & $\mathrm{CD}$ \\
\hline 29 & Broadwater & $\begin{array}{l}\text { Springs Gulch. Big Belt } \\
\text { Mountains, head of Springs Gulch } \\
\text { on south slopes of Bilk Mountain, } \\
0.3 \text { air mile southwest of the } \\
\text { eastern peak of Bilk Mountain; end } \\
\text { of Springs Gulch Road (FR 1020). }\end{array}$ & $\begin{array}{l}\text { 2004: } 30 \text { C. longistylum plants in a } \\
\text { mixed population with C. } \\
\text { hookerianum and hybrids. 1992: } \\
\text { About } 50 \text { plants; } 10 \% \text { C. longistylum, } \\
20 \% \text { C. hookerianum and the rest } \\
\text { hybrids. }\end{array}$ & $\begin{array}{l}6640-6840 \mathrm{ft} . \\
\text { Meadow, } \\
\text { roadsides. }\end{array}$ & $\mathrm{CD}$ \\
\hline 30 & Broadwater & $\begin{array}{l}\text { Long Gulch/Priest Gulch Ridge. } \\
\text { Big Belt Mountains, } 2.7 \text { air miles } \\
\text { east of east summit of Bilk } \\
\text { Mountain, ridge at the head of } \\
\text { Long and Priest gulches; and White } \\
\text { Gulch north of Whites City. }\end{array}$ & $\begin{array}{l}\text { 2004: About } 85 \text { plants in a larger } \\
\text { population containing C. hookerianum } \\
\text { and hybrids. Very weedy. 2001: } \\
\text { Estimated } 500 \text { plants, unknown how } \\
\text { many are } C \text {. longistylum. Survey } \\
\text { extended the known occurrence } \\
\text { approx. } 2 \text { miles along road toward } \\
\text { Needham Mountain. 1992: About } 500 \\
\text { individuals observed not all } C \text {. } \\
\text { longistylum. }\end{array}$ & $\begin{array}{l}5100-7010 \mathrm{ft} . \\
\text { Meadow. }\end{array}$ & B? \\
\hline 31 & Meagher & $\begin{array}{l}\text { Brooks Creek. From junction with } \\
\text { U.S. Highway } 12 \text { at Checkerboard, } \\
\text { follow FS Road } 581 \text { up Brooks } \\
\text { Creek about } 3 \text { miles. Take left fork } \\
\text { about } 0.3 \text { mile to site. }\end{array}$ & $\begin{array}{l}\text { 2004: About } 50 \text { plants, very weedy. } \\
\text { First observed in } 1992 .\end{array}$ & $\begin{array}{l}5960-6410 \mathrm{ft} . \\
\text { Meadow, open } \\
\text { forest. }\end{array}$ & $\mathrm{CD}$ \\
\hline
\end{tabular}


Table 1. Continued.

\begin{tabular}{|c|c|c|c|c|c|}
\hline EO \# & County & Survey Site & Survey Data & Description & Ranking \\
\hline 32 & Meagher & $\begin{array}{l}\text { West Fork Flagstaff Creek. From } \\
\text { junction with U.S. Highway } 12 \\
\text { about } 3 \text { miles southeast of } \\
\text { Checkerboard, follow FS Road } \\
1043 \text { about } 3.5 \text { miles to site. }\end{array}$ & $\begin{array}{l}\text { 2004: Approx. } 250 \text { plants. First } \\
\text { observation in } 1992 .\end{array}$ & $\begin{array}{l}5400-5640 \mathrm{ft} . \\
\text { Meadow, } \\
\text { riparian areas, } \\
\text { roadsides, } \\
\text { sagebrush. }\end{array}$ & $\mathrm{BC}$ \\
\hline 33 & Meagher & $\begin{array}{l}\text { Brooks Creek. From junction with } \\
\text { U.S. Highway } 12 \text { at Checkerboard, } \\
\text { follow FS Road } 581 \text { up Brooks } \\
\text { Creek about } 2 \text { miles. Site is along } \\
\text { road just inside Forest Service } \\
\text { boundary. }\end{array}$ & $\begin{array}{l}\text { 2004: No plants found. First } \\
\text { observation in } 1992 .\end{array}$ & $\begin{array}{l}5680-5770 \mathrm{ft} . \\
\text { No habitat info } \\
\text { available. }\end{array}$ & $\mathrm{F}$ \\
\hline 34 & Meagher & $\begin{array}{l}\text { West Fork Checkerboard Creek. } \\
\text { From Checkerboard, follow FS } \\
\text { Road } 581 \text { up Brooks Creek about } 5 \\
\text { miles. Site is along the south side } \\
\text { of the road beside an unnamed } \\
\text { tributary. }\end{array}$ & Only observation in 1992. & $\begin{array}{l}\text { 6350-6440 ft. } \\
\text { No habitat info } \\
\text { available. }\end{array}$ & $\mathrm{U}$ \\
\hline 35 & Meagher & $\begin{array}{l}\text { West Fork Checkerboard Creek. } \\
\text { Go about } 4 \text { miles southeast of } \\
\text { Richardson Creek Campground on } \\
\text { FS Road 211. Site runs along West } \\
\text { Fork Checkerboard Creek to the } \\
\text { southwest and northeast and on } \\
\text { Hall Creek drainage. }\end{array}$ & $\begin{array}{l}\text { 2004: Approx. } 650 \text { plants. First } \\
\text { observation in } 1992 .\end{array}$ & $\begin{array}{l}6250-6530 \mathrm{ft} . \\
\text { Riparian areas. }\end{array}$ & B \\
\hline 36 & Meagher & $\begin{array}{l}\text { East Fork Checkerboard Creek. } \\
\text { Follow FS Road } 211 \text { about } 6 \text { miles } \\
\text { southeast from Richardson Creek } \\
\text { Campground. Site is along the East } \\
\text { Fork Checkerboard Creek to the } \\
\text { north of the road; also along FS } \\
\text { roads } 585 \text { and } 581 \text {. }\end{array}$ & $\begin{array}{l}\text { 2004: Estimate of } 1,200 \text { plants. First } \\
\text { observation in } 1992 .\end{array}$ & $\begin{array}{l}6800-6960 \mathrm{ft} . \\
\text { Meadows, } \\
\text { riparian areas, } \\
\text { roadsides, } \\
\text { sagebrush. }\end{array}$ & $\mathrm{AB}$ \\
\hline 37 & Meagher & $\begin{array}{l}\text { West Fork Checkerboard Creek. } \\
\text { About } 7 \text { miles south of White } \\
\text { Sulphur Springs, take road to east } \\
\text { up Cottonwood Creek. Follow road } \\
\text { to end almost to national forest } \\
\text { boundary. Follow creek north and } \\
\text { take east fork; site begins at fork } \\
\text { and extends about } 0.5 \text { mile } \\
\text { upstream. }\end{array}$ & $\begin{array}{l}\text { 1992: } 3 \text { subpopulations documented } \\
\text { but no population data. }\end{array}$ & $\begin{array}{l}\text { 6280-6600 ft. } \\
\text { Meadow. }\end{array}$ & $\bar{U}$ \\
\hline 38 & Meagher & $\begin{array}{l}\text { Newlan Creek. Take FS Road } 830 \\
\text { off U.S. Highway } 89 \text { just south of } \\
\text { Newlan Creek guard station. } \\
\text { Follow the road about } 4 \text { miles up } \\
\text { Newlan Creek. Site is to the north } \\
\text { of road along unnamed tributary; } \\
\text { and along FS Road 830A. }\end{array}$ & $\begin{array}{l}\text { 2004: Approx. } 400 \text { individuals in a } \\
\text { larger population with } C \text {. } \\
\text { hookerianum and hybrids. First } \\
\text { observation in } 1992 .\end{array}$ & $\begin{array}{l}5800-6400 \mathrm{ft} . \\
\text { Meadows, } \\
\text { riparian areas. }\end{array}$ & B \\
\hline 39 & Meagher & $\begin{array}{l}\text { Sheep Creek. Follow U.S. Hwy } \\
89 \text { northeast from Forest Green } \\
\text { about } 2 \text { miles. Take road to right to } \\
\text { quarry about } 0.25 \text { mile. Site is } \\
\text { along unnamed tributary of Sheep } \\
\text { Creek. }\end{array}$ & $\begin{array}{l}\text { 2004: Approx. } 125 \text { plants in a larger } \\
\text { population with } C \text {. hookerianum and } \\
\text { hybrids. First observation in } 1992 .\end{array}$ & $\begin{array}{l}\text { 6200-6440 ft. } \\
\text { Roadsides. }\end{array}$ & $\mathrm{BC}$ \\
\hline 41 & Judith Basin & $\begin{array}{l}\text { Oka Butte. Take county road that } \\
\text { passes rodeo grounds north of } \\
\text { Judith Gap. Make left turn at } \\
\text { county line, go north about } 1.5 \\
\text { miles, then turn west for about } 1.7 \\
\text { miles to dirt road. Go about } 1 \text { mile, } \\
\text { turn right. Go about } 2 \text { miles to site } \\
\text { on either side of road. }\end{array}$ & A single observation from 1988. & $\begin{array}{l}5640-5760 \mathrm{ft} . \\
\text { Roadsides. }\end{array}$ & $\mathrm{U}$ \\
\hline 42 & Wheatland & $\begin{array}{l}\text { Bartleson Peak. Headwaters of } \\
\text { Hopley Creek, north side of } \\
\text { Bartleson Peak; about } 20 \text { air miles } \\
\text { northwest of Harlowton. Approach } \\
\text { possibly via FS Road } 8823 \text {. }\end{array}$ & A single observation from 1992. & $\begin{array}{l}6500-7500 \mathrm{ft} . \\
\text { Open forest. }\end{array}$ & $\bar{U}$ \\
\hline
\end{tabular}


Table 1. Continued.

\begin{tabular}{|c|c|c|c|c|c|}
\hline EO \# & County & Survey Site & Survey Data & Description & Ranking \\
\hline 45 & Meagher & $\begin{array}{l}\text { Grouse Ridge. Big Belt } \\
\text { Mountains, Trout Creek Road to } \\
\text { Dry Gulch Road, east on Beaver } \\
\text { Creek Road (FS 138) through } \\
\text { Indian Flats then east on FS Road } \\
4118 .\end{array}$ & $\begin{array}{l}\text { 2001: More than } 50 \text { mature plants } \\
\text { with many rosettes over } 2 \text { acres. }\end{array}$ & $\begin{array}{l}6610 \mathrm{ft} . \\
\text { Meadow. }\end{array}$ & $\mathrm{C}$ \\
\hline 47 & $\begin{array}{l}\text { Lewis \& } \\
\text { Clark }\end{array}$ & $\begin{array}{l}\text { Indian Flats. Big Belt Mountains. } \\
\text { Trout Creek Road to Dry Gulch } \\
\text { Road, east on Beaver Creek Road } \\
\text { (FS 138) to Indian Flats, Pike } \\
\text { Creek and Jim Ball Basin. }\end{array}$ & $\begin{array}{l}\text { 2004: } 1 \text { C. longistylum with } 12 \\
\text { hybrids and } 9 \text { C. hookerianum in Jim } \\
\text { Ball Basin. } 34 \text { rosettes present. 2001: } \\
<50 \text { plants with rosettes, covering a } \\
\text { two-mile linear strip of roadside, } \\
\text { Identification uncertain. }\end{array}$ & $\begin{array}{l}\text { 6220-6530 ft. } \\
\text { Roadsides. }\end{array}$ & $\mathrm{C}$ \\
\hline 49 & Broadwater & $\begin{array}{l}\text { Grouse Creek. Big Belt } \\
\text { Mountains, Magpie Gulch Road to } \\
\text { FS Road } 425 \text { G1. }\end{array}$ & 2001: <10 plants, very weedy. & $\begin{array}{c}\text { 6264 ft. } \\
\text { Roadsides. }\end{array}$ & $\bar{D}$ \\
\hline 50 & Broadwater & $\begin{array}{l}\text { Nary Time Gulch. Big Belt } \\
\text { Mountains, Avalanche Gulch Road } \\
\text { to Nary Time Gulch. }\end{array}$ & $\begin{array}{l}\text { 2001: >40 plants, weedy, disturbed } \\
\text { site. }\end{array}$ & $\begin{array}{l}5120-5200 \mathrm{ft} . \\
\text { Roadsides, } \\
\text { riparian areas }\end{array}$ & $\mathrm{C}$ \\
\hline 52 & Meagher & $\begin{array}{l}\text { Ohio Gulch-Benton Gulch. Big } \\
\text { Belt Mountains, Confederate } \\
\text { Gulch, to Cement Gulch, to Benton } \\
\text { Gulch and some points up Ohio } \\
\text { Gulch. }\end{array}$ & 2001: >75 plants. & $\begin{array}{l}5140-5560 \mathrm{ft} . \\
\text { Weedy riparian } \\
\text { area. }\end{array}$ & $\mathrm{C}$ \\
\hline 53 & Broadwater & $\begin{array}{l}\text { Hellgate Canyon. Big Belt } \\
\text { Mountains, Hellgate Gulch Road, } \\
\text { about } 2.5 \text { miles beyond the first } \\
\text { creek crossing. }\end{array}$ & $\begin{array}{l}\text { 2001: } 2 \text { plants in area that burned in } \\
2000 .\end{array}$ & $\begin{array}{c}5165 \mathrm{ft} . \\
\text { Weedy riparian } \\
\text { area. }\end{array}$ & $\mathrm{D}$ \\
\hline 54 & Meagher & $\begin{array}{l}\text { Elk Ridge. Approximately } 26.5 \text { air } \\
\text { miles northeast of Helena airport. } \\
\text { Take York Road; at York go to } \\
\text { Nelson, then northeast on Road } \\
\text { 138. Turn east at road to Jim Ball } \\
\text { Basin. Follow road to Elk Ridge } \\
\text { (Block Management Unit). }\end{array}$ & $\begin{array}{l}\text { 2002: >300 plants in } 2 \\
\text { subpopulations. }\end{array}$ & $\begin{array}{l}\text { 6690-6990 ft. } \\
\text { Meadow. }\end{array}$ & $\mathrm{BC}$ \\
\hline 56 & Meagher & $\begin{array}{l}\text { Dry Range. Approximately } 20 \\
\text { miles northwest of White Sulphur } \\
\text { Springs on Forest Service \& private } \\
\text { lands.. }\end{array}$ & $\begin{array}{l}\text { 2004: Approx. } 2200 \text { C. longistylum } \\
\text { plants with numerous hybrids and a } \\
\text { few C. hookerianum. 2003: Estimated } \\
10,000 \text { plants. }\end{array}$ & $\begin{array}{l}4920-6200 \mathrm{ft} . \\
\text { Meadows, open } \\
\text { forest. }\end{array}$ & A \\
\hline 57 & Judith Basin & $\begin{array}{l}\text { Hay Canyon. Little Belt } \\
\text { Mountains. Hay Canyon Road } \\
6390 . \text { Site occurs from } 0.8 \text { mile to } \\
2 \text { miles up the canyon. }\end{array}$ & $\begin{array}{l}\text { 2004: } 200 \text { plants. Counted } 47 \\
\text { flowering plants of } C \text {. longistylum and } \\
\text { putative hybrids that lean towards } C \text {. } \\
\text { longistylum. Many rosettes also in the } \\
\text { area. Population is in small meadows } \\
\text { and openings along road. }\end{array}$ & $\begin{array}{l}5410-5610 \mathrm{ft} . \\
\text { Meadows, } \\
\text { roadsides. }\end{array}$ & $\mathrm{BC}$ \\
\hline 58 & Judith Basin & $\begin{array}{l}\text { Dry Pole Canyon. Little Belt } \\
\text { Mountains. Dry Pole Canyon Road } \\
6392 \text { from bottom of drainage to } \\
\text { end of road. }\end{array}$ & $\begin{array}{l}\text { 2004: } 100-150 \text { plants. Counted } 23 \\
\text { flowering } C \text {. longistylum and putative } \\
\text { hybrids that lean towards } C \text {. } \\
\text { longistylum. Numerous rosettes also } \\
\text { encountered. }\end{array}$ & $\begin{array}{l}5400-6400 \mathrm{ft} . \\
\text { Meadows. }\end{array}$ & $\mathrm{BC}$ \\
\hline 59 & Wheatland & $\begin{array}{l}\text { Sawmill Canyon. Little Belt } \\
\text { Mountains. Along Forest Road 584, } \\
\text { Sawmill Canyon. }\end{array}$ & $\begin{array}{l}\text { 2004: } 8 \text { plants counted. Scattered } \\
\text { flowering plants and rosettes } \\
\text { throughout the drainage. } 2 \text { putative } \\
\text { hybrids also observed. }\end{array}$ & $\begin{array}{l}5410-5610 \mathrm{ft} . \\
\text { Riparian areas, } \\
\text { disturbed } \\
\text { meadows, open } \\
\text { forest. }\end{array}$ & $\mathrm{CD}$ \\
\hline 63 & $\begin{array}{l}\text { Cascade, } \\
\text { Judith Basin }\end{array}$ & $\begin{array}{l}\text { Jefferson Creek-Slide Rock. } \\
\text { Little Belt Mountains. } \\
\text { Approximately } 3 \text { miles SE of } \\
\text { Neihart along Jefferson Creek Road } \\
267 \text { and continuing up drainage to } \\
\text { Road } 3328 \text { and along Road } 251 .\end{array}$ & $\begin{array}{l}\text { 2004: Estimate of } 200 \text { plants. Mixed } \\
\text { population of } C \text {. hookerianum, } C \text {. } \\
\text { longistylum and putative hybrids. } \\
\text { Predominantly } C \text {. hookerianum in } \\
\text { lower portion of drainage with more } \\
\text { C. longistylum and hybrids higher in } \\
\text { the drainage. Total thistle population } \\
\text { in the area is approx. } 1200 \text { plants. }\end{array}$ & $\begin{array}{l}6000-7970 \mathrm{ft} . \\
\text { Roadsides, } \\
\text { riparian areas, } \\
\text { meadows. }\end{array}$ & $\mathrm{C}$ \\
\hline 64 & Fergus & $\begin{array}{l}\text { Big Snowy Mountains. About } 20 \\
\text { miles south of Lewistown. }\end{array}$ & Specimen collected in 1960. & --- & $\mathrm{H}$ \\
\hline
\end{tabular}


Table 1. Continued.

\begin{tabular}{|c|c|c|c|c|c|}
\hline EO \# & County & Survey Site & Survey Data & Description & Ranking \\
\hline 65 & Meagher & $\begin{array}{l}\text { Coates Pond. Castle Mountains. } \\
\text { From White Sulphur Springs take } \\
\text { Highway } 12 \text { east to Checkerboard; } \\
\text { travel southwest on FS Road } 581 \\
\text { about } 5 \text { miles to FS Road } 1043 \text {. } \\
\text { Site begins about } 2 \text { miles southeast. }\end{array}$ & $\begin{array}{l}\text { 2004: Estimate } 350 \text { plants; very } \\
\text { weedy. }\end{array}$ & $\begin{array}{l}6270-6290 \mathrm{ft} . \\
\text { Weedy riparian } \\
\text { area, meadow, } \\
\text { sagebrush. }\end{array}$ & $\mathrm{BC}$ \\
\hline 66 & Meagher & $\begin{array}{l}\text { Fourmile Creek. From White } \\
\text { Sulphur Springs travel east on } \\
\text { Highway 12, turn south of FS Road } \\
\text { 211. Population is scattered along } \\
\text { road adjacent to Fourmile Creek to } \\
\text { Richardson Creek Campground. }\end{array}$ & 2004: Counted 114 plants. & $\begin{array}{l}5710-5990 \mathrm{ft} . \\
\text { Roadsides, } \\
\text { meadow, } \\
\text { riparian area. }\end{array}$ & $\mathrm{C}$ \\
\hline 67 & Meagher & $\begin{array}{l}\text { Wagner Gulch. Big Belt } \\
\text { Mountains. From White Sulphur } \\
\text { Springs travel northwest on Road } \\
360 \text { to Wagner Gulch Road } 259 \text {. } \\
\text { Travel west on Wagner Gulch. }\end{array}$ & $\begin{array}{l}\text { 2004: Approx. } 100 \text { plants in a larger } \\
\text { population of } C \text {. hookerianum and } \\
\text { hybrids. }\end{array}$ & $\begin{array}{l}6380-6580 \mathrm{ft} . \\
\text { Meadows, } \\
\text { roadsides, open } \\
\text { forest. }\end{array}$ & $\mathrm{CD}$ \\
\hline 68 & $\begin{array}{l}\text { Judith Basin, } \\
\text { Meagher }\end{array}$ & $\begin{array}{l}\text { Elephant Rock. Little Belt } \\
\text { Mountains. From White Sulphur } \\
\text { Springs travel north on FS Road } \\
274 \text { about } 9 \text { miles. Population is } \\
\text { along Whitetail Creek. } \\
\end{array}$ & $\begin{array}{l}\text { 2004: Estimate of } 800-1000 \text { plants, } C \text {. } \\
\text { hookerianum and hybrids also present. }\end{array}$ & $\begin{array}{l}6000-6690 \mathrm{ft} . \\
\text { Roadsides, } \\
\text { meadows, } \\
\text { riparian areas. }\end{array}$ & $\mathrm{AB}$ \\
\hline 69 & Wheatland & $\begin{array}{l}\text { Jellison Place. Little Belt } \\
\text { Mountains. West of Harlowtown } \\
\text { take the county road off Highway } \\
89 \text { for approximately } 24 \text { miles to } \\
\text { FS land. Population is along } \\
\text { roadway. }\end{array}$ & 2004: Approx. 125 plants. & $\begin{array}{l}5800 \mathrm{ft} . \\
\text { Roadsides, } \\
\text { meadow. }\end{array}$ & $\mathrm{C}$ \\
\hline 70 & Meagher & $\begin{array}{l}\text { Spring Creek. Little Belt } \\
\text { Mountains. Travel north on FS } \\
\text { Road } 274 \text { about } 6 \text { miles to FS Road } \\
6393 \text {. Travel northeast } 3.9 \text { miles to } \\
\text { Basin Creek. }\end{array}$ & 2004: About 200 plants. & $\begin{array}{l}5600 \mathrm{ft} . \\
\text { Riparian area, } \\
\text { grassland, } \\
\text { sagebrush. }\end{array}$ & $\mathrm{C}$ \\
\hline 72 & Meagher & $\begin{array}{l}\text { South Fork Tenderfoot Creek. } \\
\text { Little Belt Mountains. Site is above } \\
\text { junction of Road } 6424 \text { and Road } \\
586 \text { to just before the crest where } \\
\text { road drops into the South Fork } \\
\text { Tenderfoot. }\end{array}$ & $\begin{array}{l}\text { 2004: Estimate of } 30-40 \text { plants, } 6 \text { of } \\
\text { them flowering. C. hookerianum and } \\
\text { hybrids also present. Many rosettes } \\
\text { present. }\end{array}$ & $\begin{array}{l}6000-6400 \mathrm{ft} . \\
\text { Roadsides, } \\
\text { riparian areas. }\end{array}$ & $\mathrm{D}$ \\
\hline
\end{tabular}

\section{E. Habitats}

C. longistylum occurs in a variety of open habitats that receive full to partial sun. The best habitats for the species occur in montane to subalpine meadows. Occurrences are also common along roadsides, herbaceous-dominated riparian areas and open forests of Douglas-fir, lodgepole pine or whitebark pine. Plants occur as low 4800 feet elevation up to approximately 8100 feet with the majority of the occurrences between approximately 6000 and 7500 feet.

Periodic disturbance appears to play a key role in the survival and establishment of populations. Establishment of seedlings in meadow populations appears to be highest in areas following disturbance by rodents churning the soil. Fire also appears to be beneficial to the species with high numbers of flowering plants and rosettes seen in the Spur Park and Ant Park areas following fire. Anthropogenic disturbance also appears to be beneficial under some circumstances. Roadsides provide habitat for the species throughout its range due to the bare soil, lack of competition and the increased availability of light, water and nutrients that are common along many mountain roads. These populations are also susceptible to the negative impacts associated with roads such as weed invasion, herbicide spraying and road grading, among other possible threats.

Species composition at local C. longistylum sites varies widely across its range and even within an individual population. Elevation and the type of habitat (meadow, open forest, riparian or roadside) occupied are significant factors in determining 
species composition. Below is a list of some of the more common species encountered, organized by lifeform.

Trees

Pseudotsuga menziesii (Douglas-fir)

Pinus contorta (lodgepole pine)

Pinus albicaulis (whitebark pine)

\section{Shrubs}

Artemisia tridentata ssp. vaseyana (mountain big sage)

Juniperus communis (common juniper)

Juniperus horizontalis (horizontal juniper)

Potentilla fruticosa (shrubby cinquefoil)

\section{Grasses}

*Bromus inermis (smooth brome)

Festuca idahoensis (Idaho fescue)

Festuca scabrella (rough fescue)

Koeleria macrantha (prairie junegrass)

*Phleum pratense (common timothy)

*Poa pratensis (Kentucky bluegrass)

Stipa richardsonii (Richardson's needlegrass)

Forbs

Achillea millefolium (common yarrow)

Agoseris glauca (false mountain dandelion)

Anemone multifida (cliff anemone)

Antennaria microphylla (rosy pussy-toes)

Arenaria congesta (ballhead sandwort)

Campanula rotundifolia (harebell)

Cerastium arvense (field chickweed)

Galium boreale (northern bedstraw)

Geranium richardsonii (white geranium)

Geranium viscosissimum (sticky geranium)

Geum triflorum (prairie smoke)

Lupinus argenteus (silvery lupine)

Potentilla gracilis (slender cinquefoil)

Solidago multiradiata (mountain goldenrod)

*Taraxacum officinale (common dandelion)

*Thlaspi arvense (field pennycress)

*non-native species

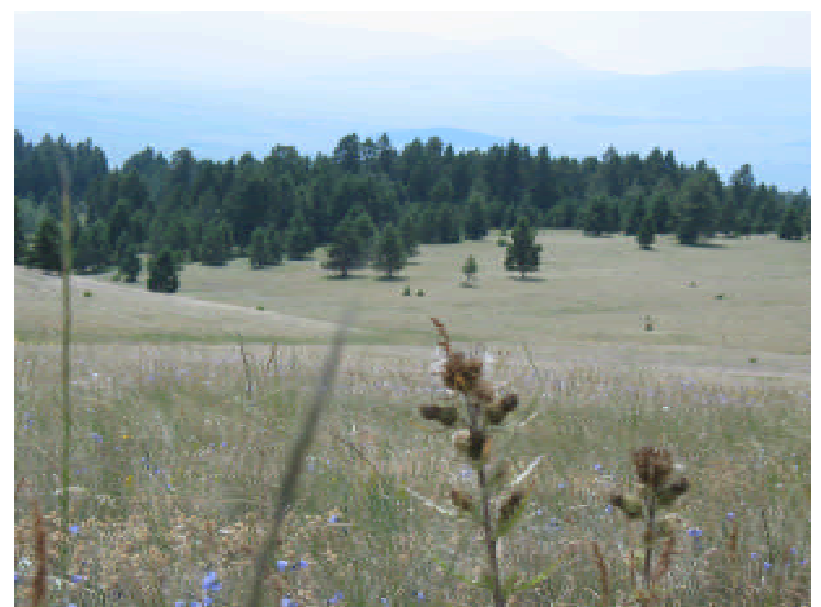

Figure 5. Cirsium longistylum habitat in the Dry Range.

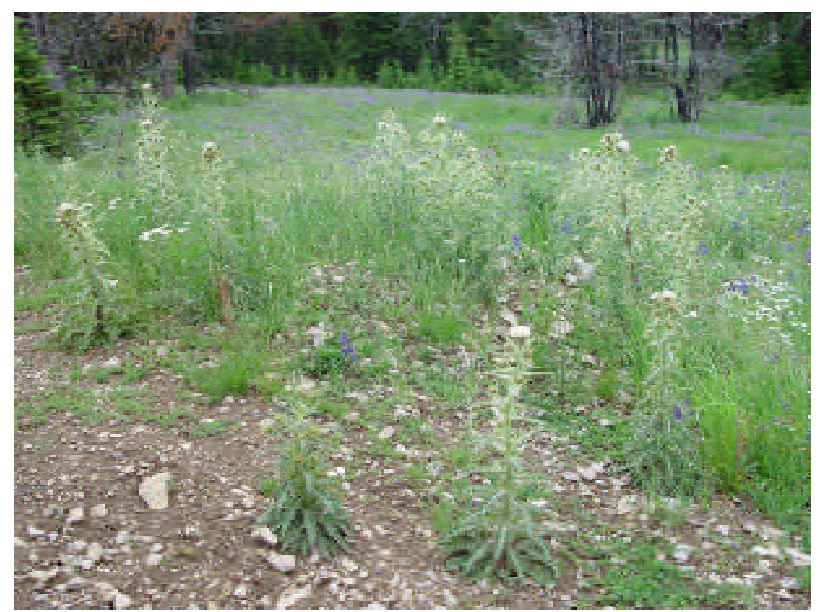

Figure 6. Cirsium longistylum habitat and flowering plants near Spur Park after fire.

Known occurrences of $C$ longistylum are predominantly on calcareous soils derived from dolomites, limestones or shales. Though intrusions of coarse-grained metamorphics are common in the Belts and the Castle Mountains, soils derived from these parent materials typically do not harbor populations of long-styled thistle. Unfortunately, good site-specific soil data are not available for most of the known populations.

\section{F. Land Ownership}

Most occurrences are on National Forest lands managed by the Helena and Lewis and Clark National Forests. Ten populations occur partially or entirely on private lands with the occurrences in the 
Dry Range and on the Bair Ranch containing two of the larger populations. The Bair Ranch population is also the only one that extends onto state trust lands adjacent to Lake Sutherlin.

\section{G. Potential Threats to Known Populations}

1. Introduced Bio-controls: Rhinocyllus conicus, an inflorescence-feeding weevil was introduced into the United States in 1969 for control of Carduus species, including Carduus nutans (musk thistle). Pre- and early post-release studies of the weevil on native Cirsium species demonstrated that the weevil showed a strong preference for Carduus species over Cirsium species in terms of oviposition, feeding and larval growth. Thus an impact on native Cirsium species was not expected (Louda and Arnett 2000, Louda 1998). However, Rhinocyllus conicus is now prevalent on Cirsium longistylum and many other native thistles including Cirsium undulatum, C. hookerianum, $C$. centaureae, C. scopulorum and C. canescens in the Rocky Mountain West (Louda and Arnett 2000). Studies by Louda and others (1997) show reductions in viable seed up to $86 \%$ in $C$. canescens and an average reduction of $72 \%$ in Cirsium undulatum in Colorado and South Dakota. Seed reduction in C. longistylum during 1991 and 1992 was estimated at $61 \%$ and $46 \%$ respectively at one site in the Little Belt Mountains (Heidel 1994). Infestation rates are typically highest on the terminal or oldest flower heads while later developing flower heads and seeds may escape predation. Monitoring of infestation rates by the U.S. Forest Service at the Kings Hill site in the Little Belt Mountains produced the following percentages for 1991-1993 respectively: 80\%, $72 \%$ and $0 \%$ of flowers infested. The elimination of the weevil at the site in 1993 is believed to be the result of a late August snow in 1992 that ended the growing season early and prevented the weevil from completing its life cycle (Heidel 1994).

Surveys of C. longistylum populations in 2004 did not systematically document infestation rates, though random sampling of mature flower heads found the majority of heads infested with weevil

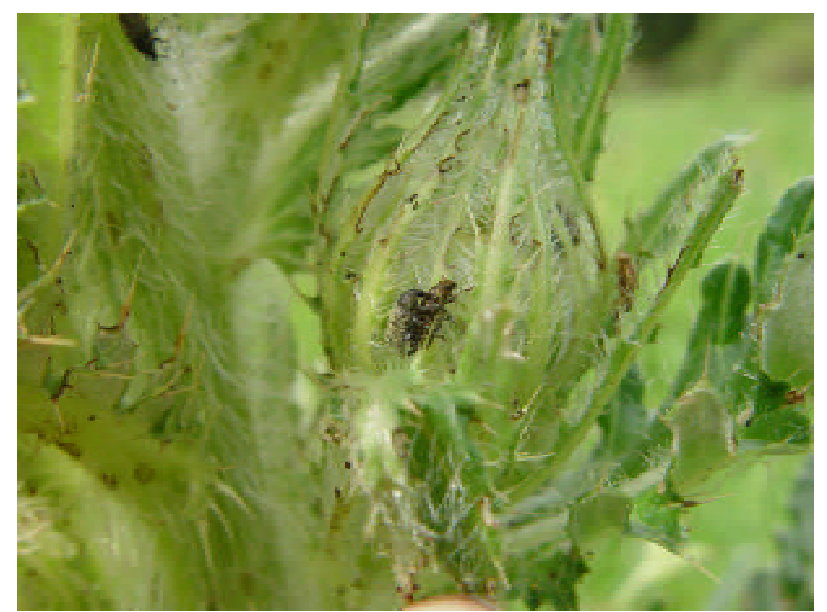

Figure 7. Rhinocyllus conicus weevils on $C$. longistylum in the Little Belt Mountains.

larvae. It was also noted that later maturing flowering heads were typically uninfested due to inappropriate timing of their development with the life stages of the weevil. This incomplete synchrony of the thistles' and weevils' life cycles has also been documented by Herr (2000) in $C$. occidentale and by Louda (1998) in C. pitcheri, a federally threatened species. Additionally, the results of Herr's seed bank and seed addition experiments on $C$. occidentale, in conjunction with an average seed destruction rate of $21 \%$ across all flower heads, indicate that a significant reduction in seedling establishment is not expected.

Though the weevil appears to have a significant impact on the total number of viable seeds produced it is unclear whether this will lead to a long-term decline of long-styled thistle populations since a percentage of seeds, particularly from late maturing heads, escape predation. Field observations from 1990-2004 have documented good establishment of rosettes at many sites even though weevils have been present in the populations, providing some evidence that enough seeds escape predation to maintain populations.

2. Hybridization: Hybridization and introgression of C. longistylum with other Cirsium species, particularly $C$. hookerianum is another potentially threat to the long-term viability of $C$. longistylum. Many populations possess individuals with involucral bract characteristics that are intermediate between the two species (Schassberger 1991, 
Poole and Heidel 1993). These intermediate bract characteristics have been noted in populations where only a few plants of $C$. hookerianum are present. This leads to the possibility that only a few flowering individuals of $C$. hookerianum may be enough to contaminate the gene pool of $C$.

longistylum. However, Brunsfeld and Baldwin's (1995) genetic analysis provided evidence that $C$. longistylum is genetically distinct from its closest relatives in west-central Montana and that putative hybrids are genetically similar to "pure" $C$.

longistylum. Their study also showed that $C$. longistylum possesses more variability than the other species sampled but it is unclear whether this is due to hybridization with the other thistles. Until wider-ranging and more in-depth genetic studies of C. longistylum and related species are completed it is unclear what, if any, affect gene flow among Cirsium species in central Montana may be having on $C$. longistylum.

\section{Recreation: Off-road vehicle use has}

historically occurred in areas occupied by the thistle and was noted in limited areas during recent field surveys. However, this activity is not believed to have a significant direct impact on the species' potential for long-term survival as long as use does not significantly increase. Indirectly, off-road vehicles and traffic on designated routes may impact populations through the spread of weed seeds and the subsequent establishment of new weed infestations into $C$. longistylum habitat.

\section{Weed Invasion and Herbicides: As noted} above, weed invasion of $C$. longistylum habitat and populations is an increasing threat to the short-term survival of populations and the long-term survival of the species. Several non-native plant species are of particular concern, including Cirsium arvense (Canada thistle), Bromus inermis (smooth brome) and Phleum pratense (common timothy). The first species is a state of Montana designated noxious weed and, as such, landowners are required to eradicate or control populations on their land. Canada thistle is a perennial that reproduces from wind dispersed seeds and rhizomes and is capable of rapid expansion and long-distance dispersal. The habitat requirements of Canada thistle overlap with that of long-styled thistle and include montane meadows, riparian areas and roadsides. At present, populations of Canada thistle occur throughout the range of long-styled thistle, though it currently is not having a significant adverse impact.

Bromus inermis and Phleum pratense have long been used as pasture grasses and for revegetation projects following fires and other natural and human-caused disturbances. Both species inhabit montane to subalpine meadows and roadsides where they may form dense stands that preclude the germination and establishment of $C$. longistylum. Bromus inermis is of particular concern in that it is a deep-rooted sod-forming grass that appears to exclude other species and is already prevalent in many lower quality $C$.

longistylum populations. As this species is not a listed noxious weed in the state it is generally not controlled and in fact it is still seeded for forage and revegetation projects. As such, B. inermis potentially poses the biggest threat to $C$. longistylum populations of all wildland weeds.

Many other non-native species have routinely been documented during surveys for long-styled thistle, including Carduus nutans, Cirsium vulgare, Cynoglossum officinale, Poa pratensis, Taraxacum officinale (common dandelion) and Thlaspi arvense (field pennycress). Further monitoring of $C$. longistylum populations is required to determine the impact that invasive weeds are having on individual populations and on the long-term viability of the species. Due to the network of roads that occur throughout the range and habitat of $C$. longistylum, expansion of nonnative species should be expected in the future and weed control and eradication measures should be implemented as appropriate.

Herbicide spraying directly on $C$. longistylum plants has been noted during past surveys, particularly along roadsides. This detrimental activity, though limited in scope, is easily preventable by increasing awareness of the species and the distinction between native and exotic thistles. 
5. Grazing: Grazing is a historical and current use in many areas occupied by long-styled thistle. Consumption of flowering stalks and rosettes by cattle has been observed (Figures 8-9) in the field, though this is usually minimal as long as more palatable vegetation is present. Livestock may have an indirect adverse impact by spreading weeds into previously uninfested areas. However,

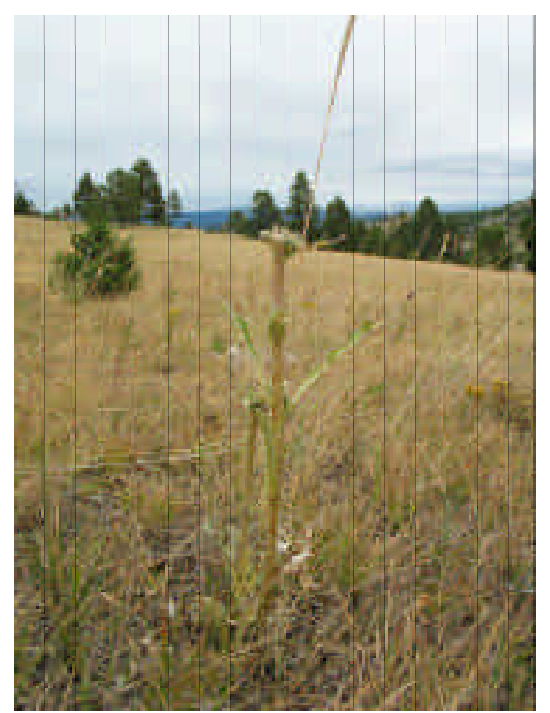

livestock grazing may reduce competition and increase bare soil, leading to an increase in germination and establishment of $C$. longistylum in some sites. Currently, light to moderate grazing is not believed to have direct significant adverse impacts on the long-term survival of the species, though short-term adverse impacts may occur in localized areas.

Figures 8-9. Grazing impacts on Cirsium longistylum. 


\section{ASSESSMENT AND RECOMMENDATIONS}

\section{A. General Assessment of Trends and Status}

As of 2004, 47 extant occurrences of Cirsium longistylum are known across the species' range. Of these, seven are ranked as having "excellent" or "good to excellent" long-term viability, another five have "good" viability and an additional seven have "good to fair" estimated viability. The seven highest quality populations, totaling approximately 18,000 plants, represent the majority of the documented/estimated plants in 2004. However, the majority of occurrences occupy roadsides, have low population numbers and/or inhabit degraded habitats that result in fair to poor long-term estimated viability for those populations.

Both long-term and short-term trends for the species are not readily apparent. Surveys previous to 2004 did not thoroughly document the extent of many populations and/or population estimates were vague, imprecise or even non-existent. However, data from several populations suggest that populations have remained relatively stable over two decades with large yearly fluctuations possible. Germination and establishment of new plants appears to be partially dependent on several factors, including climate patterns and periodic disturbance from fire, rodent activity, grazing or other sources that result in a favorable seedbed. Flowering of plants appears to be partially related to availability of adequate moisture and nutrients. Disturbances such as fire that increase both of these factors may lead to increased flowering the following year or two, as was seen in the Ant Park and Spur Park areas in the Little Belts. Large variations in rosette numbers and flowering plants is possible over a time period of several years, meaning that many years of population data are needed to accurately estimate trends.
Demographic monitoring plots (Figures 10-12) established in 1990 by the Montana Natural Heritage Program provide limited data on population trends at three sites. Since these plots were not established for the purpose of population monitoring, their limited number and size do not provide a good overall picture. All three sites show flowering plants in 2004 within the range of variation measured in the early 1990's. Rosettes have declined in 2004 relative to counts in the 1990's at the Kings Hill and Neihart sites. In contrast, the Russian Creek site shows a slight population increase in 2004 over past counts.

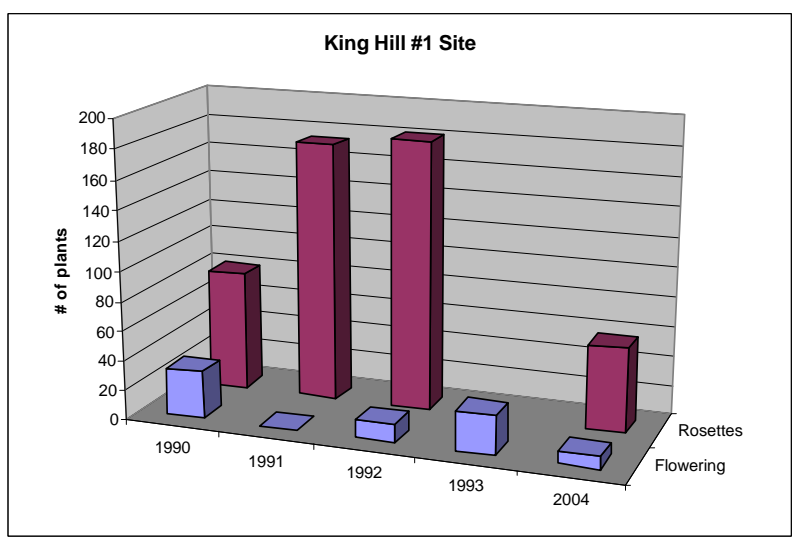

Figure 10. Permanent monitoring plot (15' radius) near Kings Hill, Little Belt Mountains. No data is available for rosettes in 1993.

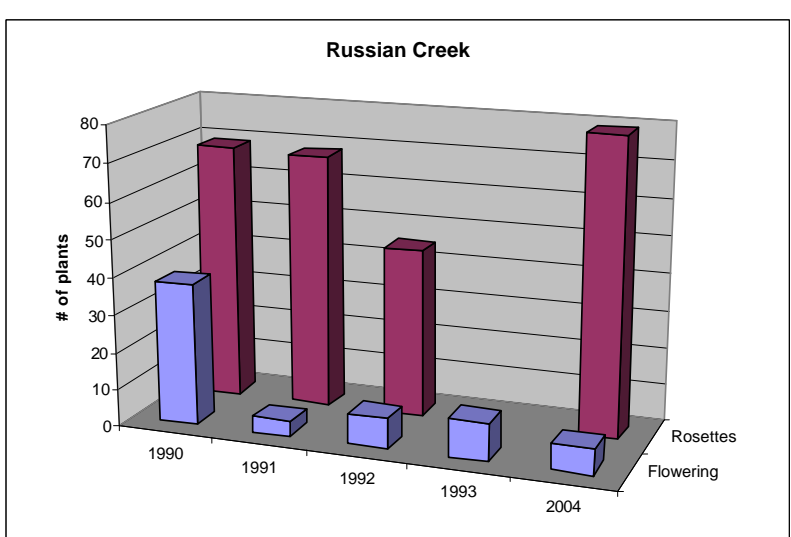

Figure 11. Permanent monitoring plot (37' radius) near Russian Creek, Little Belt Mountains. No data is available for rosettes in 1993. 


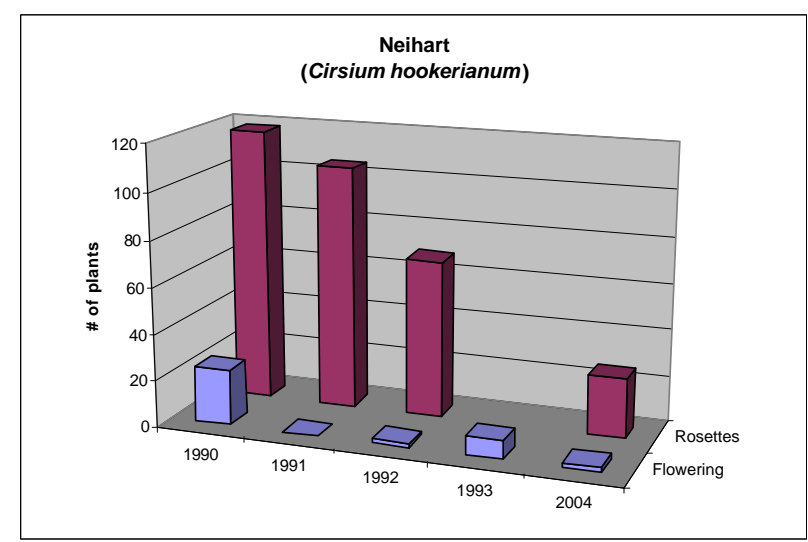

Figure 12. Permanent monitoring plot (15' radius) near Neihart, Little Belt Mountains. No data is available for rosettes in 1993. This plot is actually occupied by $C$. hookerianum, not C. longistylum.
A final semi-quantitative assessment was conducted using the approaches outlined by Regan, Master and Hammerson (2004) and adapted by the Montana Natural Heritage Program for use in ranking Animal Species of Concern (MTNHP 2004). Both of these similar assessment methods assign points to factors such as number of occurrences, population size, area or range extent, trends and threats. Some factors may not be used if data is missing or an estimate of the parameter is too uncertain. The points from the most pertinent criteria are added together to form a final score for the species. Lastly, a heritage rank of 1 to 5 at a global and/or state level is assigned based on the final score. The ranking criteria and scores assigned to $C$. longistylum are found in Table 2 using the two slightly different scoring methods.

Table 2. Ranking factors and assigned scores for the C. longistylum assessment. The first numbers in the Point Allocation column are those used in the scoring method of Regan, Master and Hammerson (2004) and the second numbers in the column are those used in the method outlined by the MTNHP State rank criteria for Animal Species of Concern. See Regan, Master and Hammerson (2004) and MTNHP (2004) for a complete discussion of the methodologies.

\begin{tabular}{|c|c|c|c|}
\hline Factor & Parameter Estimate & Category & Point Allocation \\
\hline \# of Occurrences & $21-80$ & $\mathrm{C}$ & 3/Not used \\
\hline $\begin{array}{l}\text { Condition of } \\
\text { Occurrences }\end{array}$ & $\begin{array}{l}\text { Some (13-40) with good } \\
\text { or excellent viability }\end{array}$ & $\mathrm{D}$ & 0/Not used \\
\hline Population Size & $10,000-100,000$ plants & $\mathrm{F}$ & $0 / 0$ \\
\hline $\begin{array}{c}\text { Area of } \\
\text { Occupancy }\end{array}$ & $\begin{array}{c}20-100 \mathrm{~km} 2(5,000- \\
25,000 \text { acres })\end{array}$ & $\mathrm{D}$ & Not used/0.25 \\
\hline $\begin{array}{l}\text { Geographic } \\
\text { Range }\end{array}$ & $\begin{array}{c}1,000-5,000 \mathrm{~km} 2(400- \\
2,000 \text { sq. miles })\end{array}$ & $\mathrm{D}$ & Not used/Not used \\
\hline Long-term Trend & $\begin{array}{c}\text { Relatively stable (+- } 25 \% \\
\text { change) }\end{array}$ & $\mathrm{E}$ & 0 \\
\hline Short-term Trend & $\begin{array}{l}\text { Short-term trend } \\
\text { unknown }\end{array}$ & $\mathrm{U}$ & Not used/Not used \\
\hline Threats-Severity & Low to moderate & \multirow{3}{*}{ C-D } & \multirow{3}{*}{$-0.38 /-0.38$} \\
\hline Threats-Scope & Moderate? & & \\
\hline $\begin{array}{c}\text { Threats- } \\
\text { Immediacy }\end{array}$ & Moderate to high & & \\
\hline $\begin{array}{c}\text { Intrinsic } \\
\text { Vulnerability }\end{array}$ & $\begin{array}{c}\text { Not intrinsically } \\
\text { vulnerable to moderately } \\
\text { vulnerable }\end{array}$ & $\mathrm{B}-\mathrm{C}$ & Not used/Not used \\
\hline \multirow[t]{4}{*}{$\begin{array}{l}\text { Environmental } \\
\text { Specificity }\end{array}$} & \multirow[t]{4}{*}{$\begin{array}{c}\text { Narrow specialist with } \\
\text { key requirements } \\
\text { common }\end{array}$} & B & Not used/Not used \\
\hline & & $\begin{array}{l}\text { Initial Point } \\
\text { Allocation }\end{array}$ & $0 / 3.5$ \\
\hline & & Score & $2.62 / 2.87$ \\
\hline & & Rank & G3-S3/G3-S3 \\
\hline
\end{tabular}


The assignment of the threat attributes of severity, scope and immediacy is still a mostly subjective process and as such is open to interpretation and discussion. The two most apparent threats to the viability of the species appear to be from competition and loss of habitat due to weed invasion and from seed predation by the Rhinocyllus weevil. In terms of weed invasion, roadside sites and lower elevation populations are currently most affected by weeds. Higher elevation sites typically have very few weeds that are currently posing problems and/or are not immediately threatened by invasion of weeds that are likely to cause major problems in these colder environments. This may change if new weeds that possess the ability to rapidly reproduce and spread become established in these montane and subalpine meadows.

The introduced bio-control weevil has already invaded most, if not all, of the populations of $C$. longistylum. However, weevil population levels at the higher elevation sites are probably cyclical in central Montana due to variations in yearly weather. Cold weather and associated snowfalls early or late in the growing season appear to have a significant affect on the weevils' ability to survive and reproduce, resulting in significant declines or local eradication of the weevil for short time spans. When coupled with the lack of data on the influence that seed predation from the weevil is having on long-styled thistle populations, it becomes difficult to assign an accurate threat ranking, particularly in terms of severity.

\section{B. Status Recommendation}

Population estimates of approximately 30,000 plants, including seven high quality populations, scattered over four mountain ranges are promising for the long-term viability of the species. Habitat in the largest populations is generally of high quality with few if any problem weeds posing significant and immediate threats. In the near future, little change in habitat quality is expected in these populations. Sites are mostly on National Forest lands that provide a degree of protection and two large populations on private lands that have a history of light to moderate grazing appear stable. Also of benefit at this time is the active weed control program employed by the private landowners on their lands.

Long- and short-term population trends are difficult to gauge due to the lack of good survey data over many years. However, available data and observations provide some evidence that population levels have at least remained fairly stable over the past decade, with significant yearly fluctuations possible. Threats posed by invasive weeds and the introduced bio-control agent do provide reason for concern. Thus, population monitoring of long-styled thistle should continue in the future.

As a result of this assessment, the Montana Natural Heritage Program ranking of the species will change from the current G2/S2 to a G3/S3 (see Appendix A: Global/State Rank Definitions). 


\section{Literature Cited}

Brunsfeld, S.J. and C.T. Baldwin. 1994. Preliminary genetic analysis of Cirsium longistylum (long-styled thistle), a candidate threatened species. Unpublished report to the U.S. Fish and Wildlife Service. Wildland Plant Ecogenetics Cooperative, University of Idaho in cooperation with the Montana Natural Heritage Program, Helena, MT. 20 pp.

Dorn, R. 1984. Vascular plants of Montana. Mountain West Publishing. Cheyanne, WY. 276 pp.

Gardner, R.C. 1974. Systematics of Cirsium (Compositae) in Wyoming. Madrono 22:239-265.

Heidel, B. 1994. Monitoring study of Cirsium longistylum (long-styled thistle), a candidate threatened species. Montana Natural Heritage Program. Helena, MT. 32 pp.

Holmgren P.K. and N.H. Holmgren. 1990. Index Herbariorum, Edition 8: Part I. The Herbaria of the World. New York Botanical Garden Press. 704 pp. on-line (http://207.156.243.8/emu/ih/index.php).

Louda, S.M. 1998. Population growth of Rhinocyllus conicus (Coleoptera: Curculionidae) on two species of native thistles in prairie. Environmental Entomology 27(4): 834-841.

Louda, S.M. and A.E. Arnett. 2000. Predicting non-target ecological effects of biological control agents: evidence from Rhinocyllus conicus. Proceedings of the $\mathrm{X}$ International Symposium on Biological Control of Weeds. 4-14 July 1999. Montana State University, Bozeman, MT. pp 551567.

Louda, S.M., D. Kendall, J. Connor and D. Simberloff. 1997. Ecological effects of an insect introduced for the biological control of weeds. Science 277:1088-1090.
Mathews, S. 1990. Cirsium longistylum project: summary report (chromosome counts). Montana State University, Bozeman for the Montana Natural Heritage Program. 3 pp.

Mincemoyer S.A. 2004. Plant species of concern survey form. On file at the Montana Natural Heritage Program. Helena, MT.

Montana Natural Heritage Program. 2004. State rank criteria for animal species of concern. on-line (http://nhp.nris.state.mt.us/animal/index.html).

Moore, R. J. and C. Frankton. 1974. The thistles of Canada. Research Branch Canada Department of Agriculture. Monograph No. 10. Ottawa, Canada. 111 pp.

Moore, R. J. and C. Frankton. 1963. Cytotaxonomic notes on some Cirsium species of the western United States. Canadian Journal of Botany 441: 1553-1567.

Olsen, L. 2003. Sensitive plant surveys in the Dry Range, Helena National Forest. Unpublished report on file at the Helena National Forest. Helena, MT.

Ownbey, G.B. and Y. Hsi. 1963. Chromosome numbers in some North American species of the genus Cirsium. Rhodora 65:339-354.

Poole, J.M. and B.L. Heidel. 1993. Sensitive plant surveys in the Big Belts and Elkhorn Mtns., Helena National Forest. Montana Natural Heritage Program. Helena, MT. 129 pp.

Regan, T.J., L.L. Master and G.A. Hammerson. 2004. Capturing expert knowledge for threatened species assessments: a case study using NatureServe conservation status ranks. Acta Oecologica 26:95-107.

Schassberger, L.A. 1991. Report on the conservation status of Cirsium longistylum, a candidate threatened species. Montana Natural Heritage Program. Helena, MT. 92 pp. 
USDA NRCS. 2004. The PLANTS Database, Version 3.5 (http://plants.usda.gov). National Plant Data Center, Baton Rouge, LA 70874-4490 USA.

U.S. Department of Interior. 1990. Endangered and threatened wildlife and plants; review of plant taxa for listing as endangered or threatened species; notice of review. Federal Register 50 CFR Part 17:

6184-6299. 


\section{Appendix A. Global/State Rank Definitions}




\section{Heritage Program Ranks}

The international network of Natural Heritage Programs employs a standardized ranking system to denote global (range-wide) and state status. Species are assigned numeric ranks ranging from 1 to 5, reflecting the relative degree to which they are "at-risk". Rank definitions are given below. A number of factors are considered in assigning ranks - the number, size and distribution of known "occurrences" or populations, population trends (if known), habitat sensitivity, and threat. Factors in a species' life history that make it especially vulnerable are also considered (e.g., dependence on a specific pollinator).

Global Rank Definitions (NatureServe 2003)

G1 Critically imperiled because of extreme rarity and/or other factors making it highly vulnerable to extinction

G2 Imperiled because of rarity and/or other factors making it vulnerable to extinction

G3 Vulnerable because of rarity or restricted range and/or other factors, even though it may be abundant at some of its locations

G4 Apparently secure, though it may be quite rare in parts of its range, especially at the periphery

G5 Demonstrably secure, though it may be quite rare in parts of its range, especially at the periphery

T1-5 Infraspecific Taxon (trinomial) - The status of infraspecific taxa (subspecies or varieties) are indicated by a "T-rank" following the species' global rank

\section{State Rank Definitions}

S1

S2

S3

S4

S5
At high risk because of extremely limited and potentially declining numbers, extent and/or habitat, making it highly vulnerable to extirpation in the state At risk because of very limited and potentially declining numbers, extent and/or habitat, making it vulnerable to extirpation in the state

Potentially at risk because of limited and potentially declining numbers, extent and/or habitat, even though it may be abundant in some areas

Uncommon but not rare (although it may be rare in parts of its range), and usually widespread. Apparently not vulnerable in most of its range, but possibly cause for long-term concern Common, widespread, and abundant (although it may be rare in parts of its range). Not vulnerable in most of its range

\section{Combination Ranks}

G\#G\# or S\#S\# Range Rank-A numeric range rank (e.g., G2G3) used to indicate uncertainty about the exact status of a taxon

QUALIFIERS

NR

Not ranked

Q
Questionable taxonomy that may reduce conservation priority-Distinctiveness of this entity as a taxon at the current level is questionable; resolution of this uncertainty may result in change from a species to a subspecies or hybrid, or inclusion of this taxon in another taxon, with the resulting taxon having a lower-priority (numerically higher) conservation status rank 
Presumed Extinct-Species believed to be extinct throughout its range. Not located despite intensive searches of historical sites and other appropriate habitat, and virtually no likelihood that it will be rediscovered

$\mathrm{H} \quad$ Possibly Extinct—Species known from only historical occurrences, but may never-theless still be extant; further searching needed

Unrankable - Species currently unrankable due to lack of information or due to substantially conflicting information about status or trends

HYB Hybrid-Entity not ranked because it represents an interspecific hybrid and not a species

Inexact Numeric Rank-Denotes inexact numeric rank

$\mathrm{C}$

Captive or Cultivated Only-Species at present is extant only in captivity or cultivation, or as a reintroduced population not yet established

Accidental-Species is accidental or casual in Montana, in other words, infrequent and outside usual range. Includes species (usually birds or butterflies) recorded once or only a few times at a location. A few of these species may have bred on the one or two occasions they were recorded

Z Zero Occurrences-Species is present but lacking practical conservation concern in Montana because there are no definable occurrences, although the taxon is native and appears regularly in Montana

Potential—Potential that species occurs in Montana but no extant or historic occurrences are accepted

R Reported-Species reported in Montana but without a basis for either accepting or rejecting the report, or the report not yet reviewed locally. Some of these are very recent discoveries for which the program has not yet received first-hand information; others are old, obscure reports

SYN Synonym — Species reported as occurring in Montana, but the Montana Natural Heritage Program does not recognize the taxon; therefore the species is not assigned a rank

A rank has been assigned and is under review. Contact the Montana Natural Heritage Program for assigned rank

B Breeding - Rank refers to the breeding population of the species in Montana 


\section{Appendix B. Element Occurrence Rank Definitions}




\section{Element Occurrence Rank Definitions}

A - Excellent estimated viability/ecological integrity

A? - Possibly excellent estimated viability/ecological integrity

$\mathrm{AB}$ - Excellent or good estimated viability/ecological integrity

AC - Excellent, good, or fair estimated viability/ecological integrity

B - Good estimated viability/ecological integrity

B? - Possibly good estimated viability/ecological integrity

$\mathrm{BC}$ - Good or fair estimated viability/ecological integrity

BD - Good, fair, or poor estimated viability/ecological integrity

C - Fair estimated viability/ecological integrity

C? - Possibly fair estimated viability/ecological integrity

CD - Fair or poor estimated viability/ecological integrity

D - Poor estimated viability/ecological integrity

D? - Possibly poor estimated viability/ecological integrity

E - Verified extant (viability/ecological integrity not assessed)

$F$ - Failed to find

F? - Possibly failed to find

$\mathrm{H}$ - Historical

H? - Possibly historical

$X$ - Extirpated

$\mathrm{X}$ ? - Possibly extirpated

U - Unrankable

NR - Not ranked 


\section{Appendix C. Element Occurrence Maps for Cirsium LONGISTYLUM}


Figure 1. Extant Occurrences of Cirsium longistylum in the northern Big Belts C-2

Figure 2. Extant Occurrences of Cirsium longistylum in the central and southern Big Belts and the western Castle Mountains

Figure 3. Extant Occurrences of Cirsium longistylum in the Dry Range and the western Little Belt Mountains

Figure 4. Extant Occurrences of Cirsium longistylum in the northern Little Belts ............................. -5

Figure 5. Extant Occurrences of Cirsium longistylum in the central and southern Little Belts ............ C-6

Figure 6. Extant Occurrences of Cirsium longistylum in the Castle Mountains and Bair Ranch areas C-7

Figure 7. Extant Occurrences of Cirsium longistylum in the eastern Little Belts C-8 


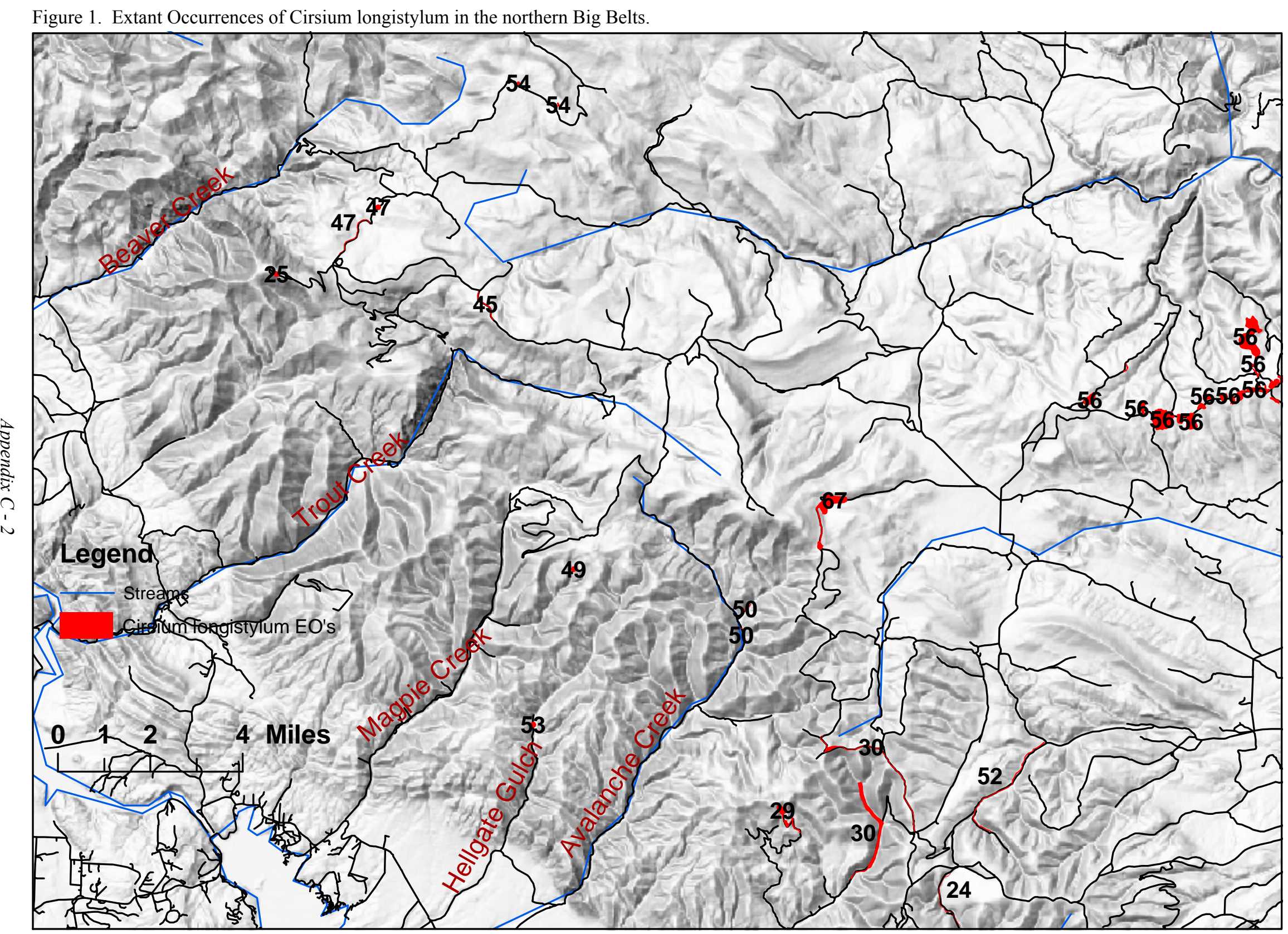




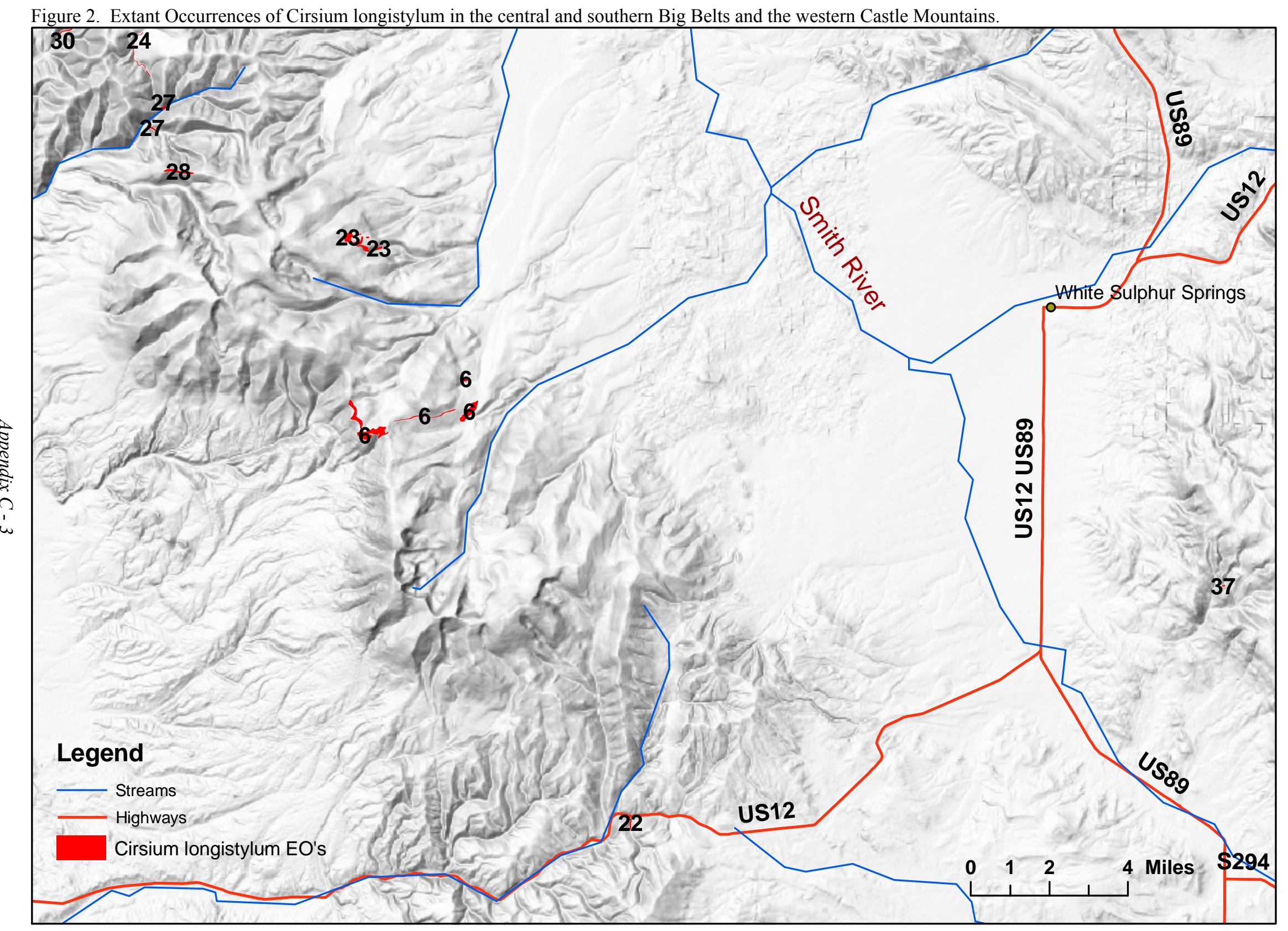


Figure 3. Extant Occurrences of Cirsium longistylum in the Dry Range and the western Little Belt Mountains.

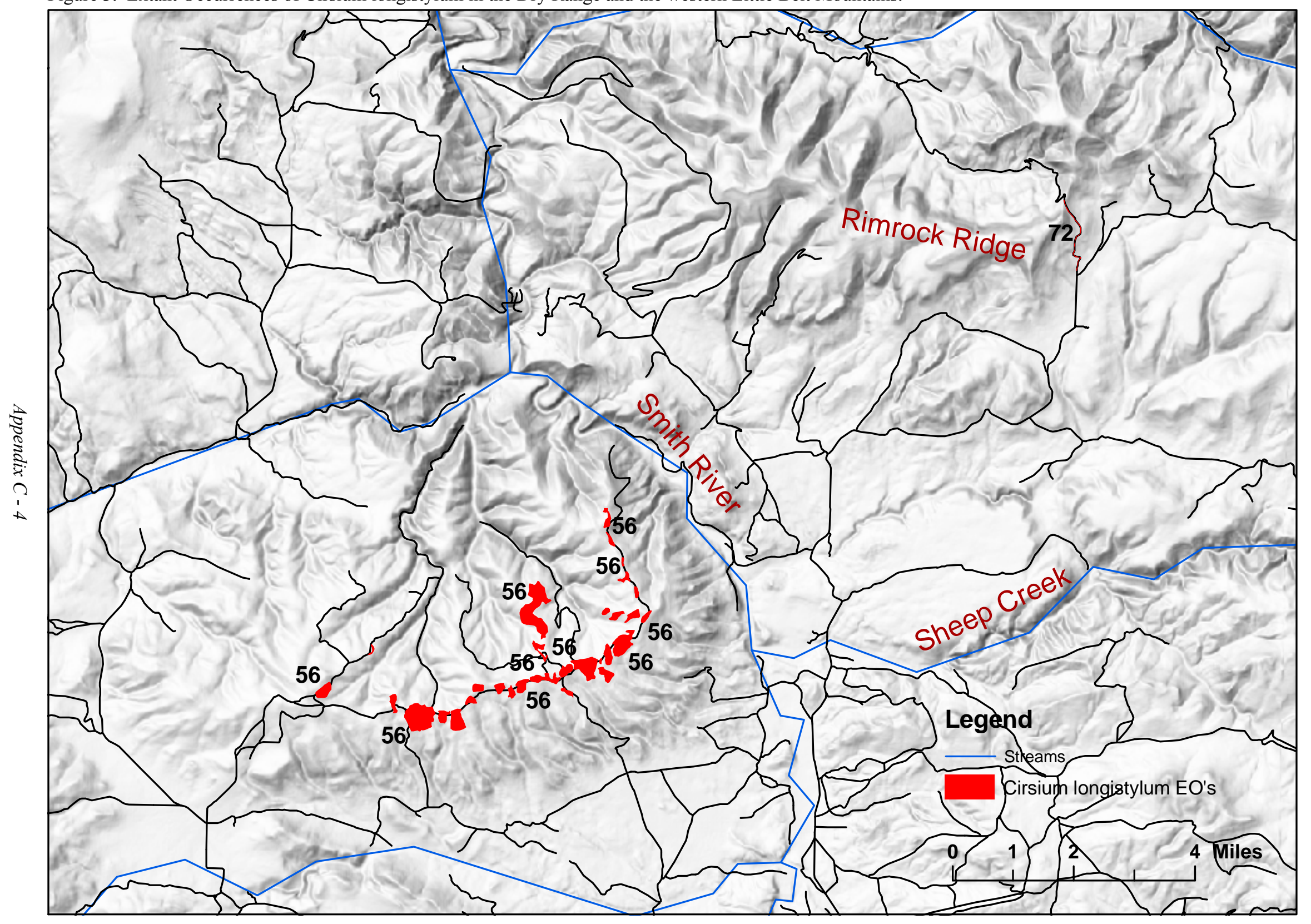


Figure 4. Extant Occurrences of Cirsium longistylum in the northern Little Belts.

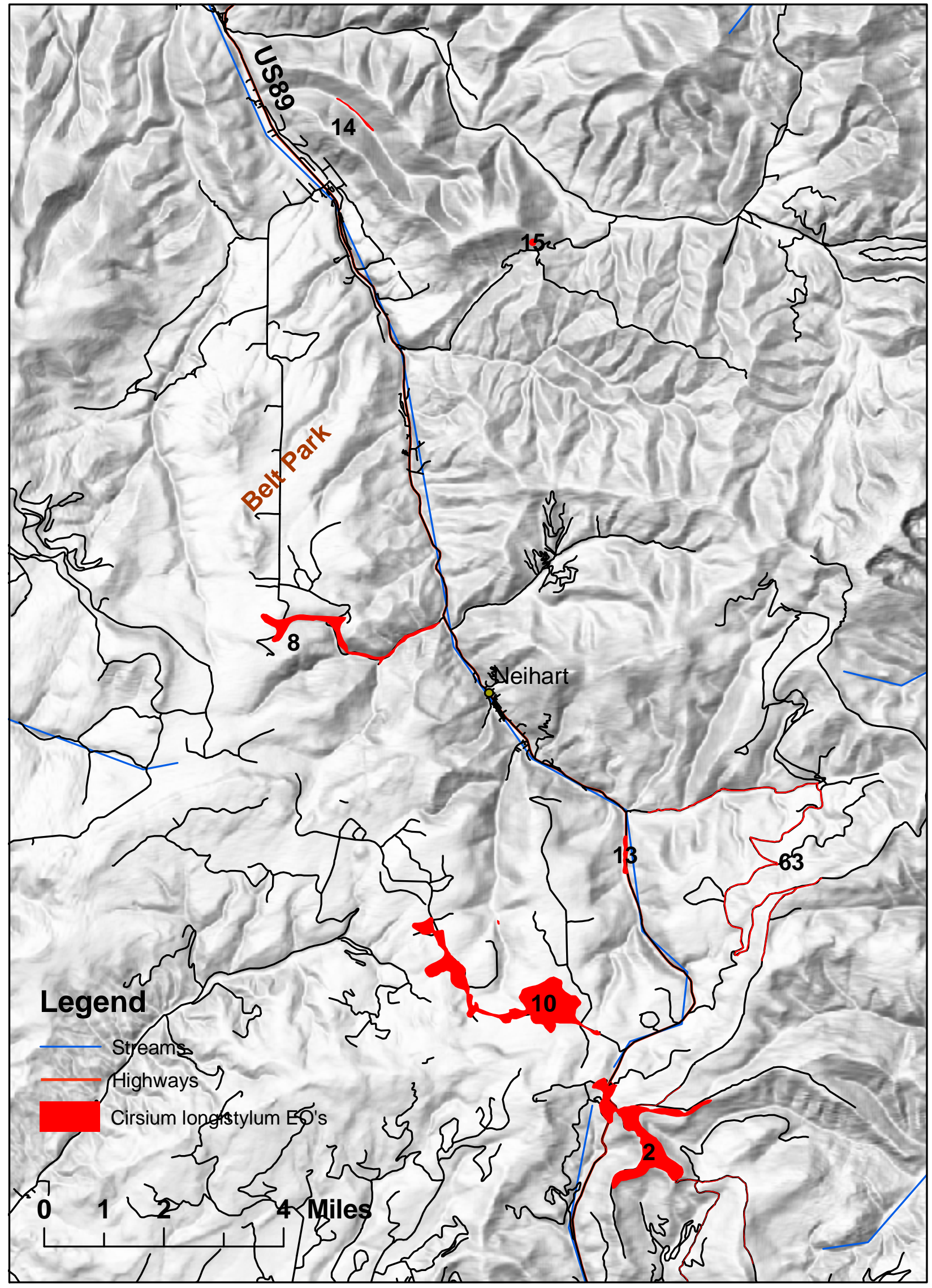

Appendix $C$ - 5 
Figure 5. Extant Occurrences of Cirsium longistylum in the central and southern Little Belts.

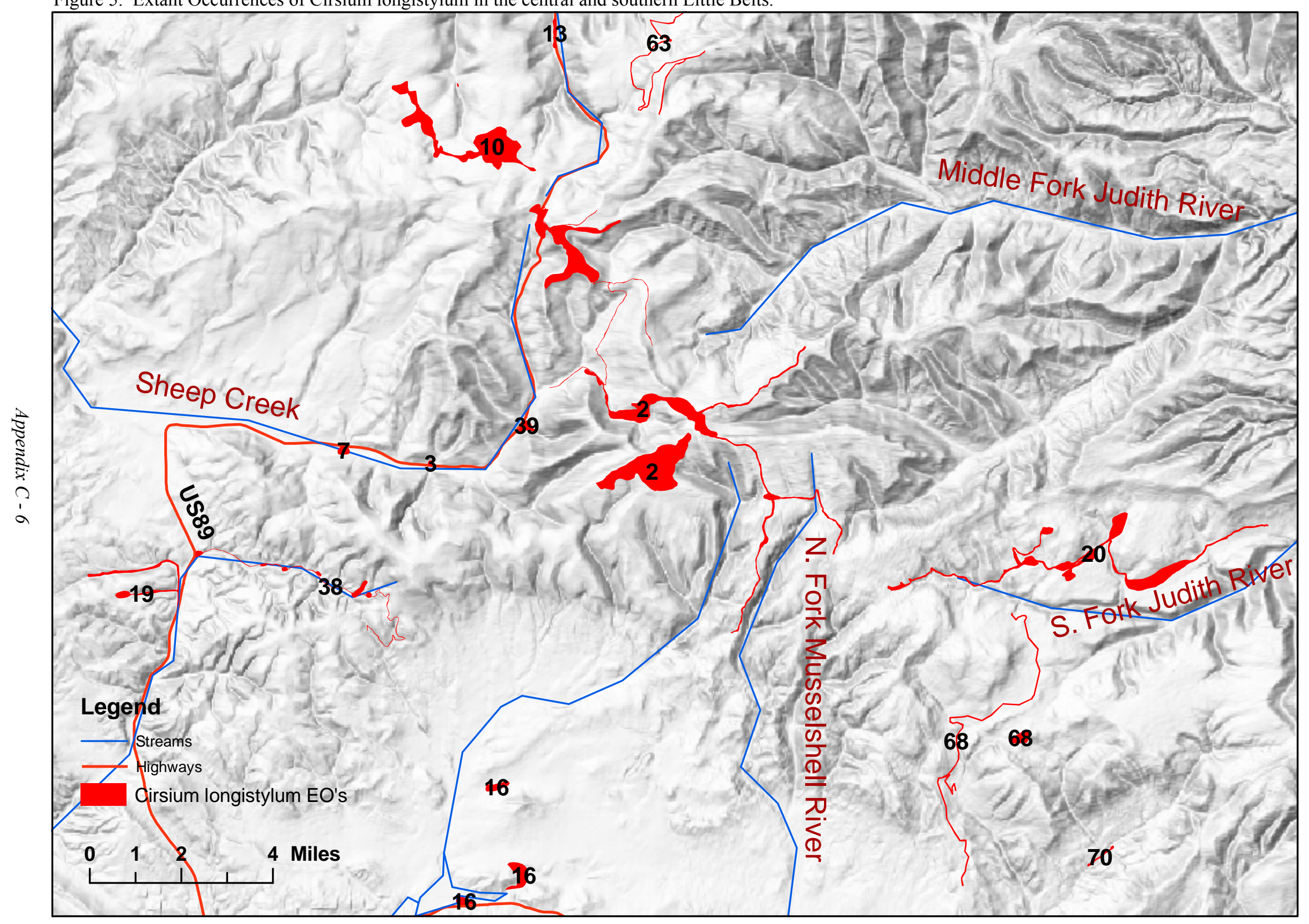




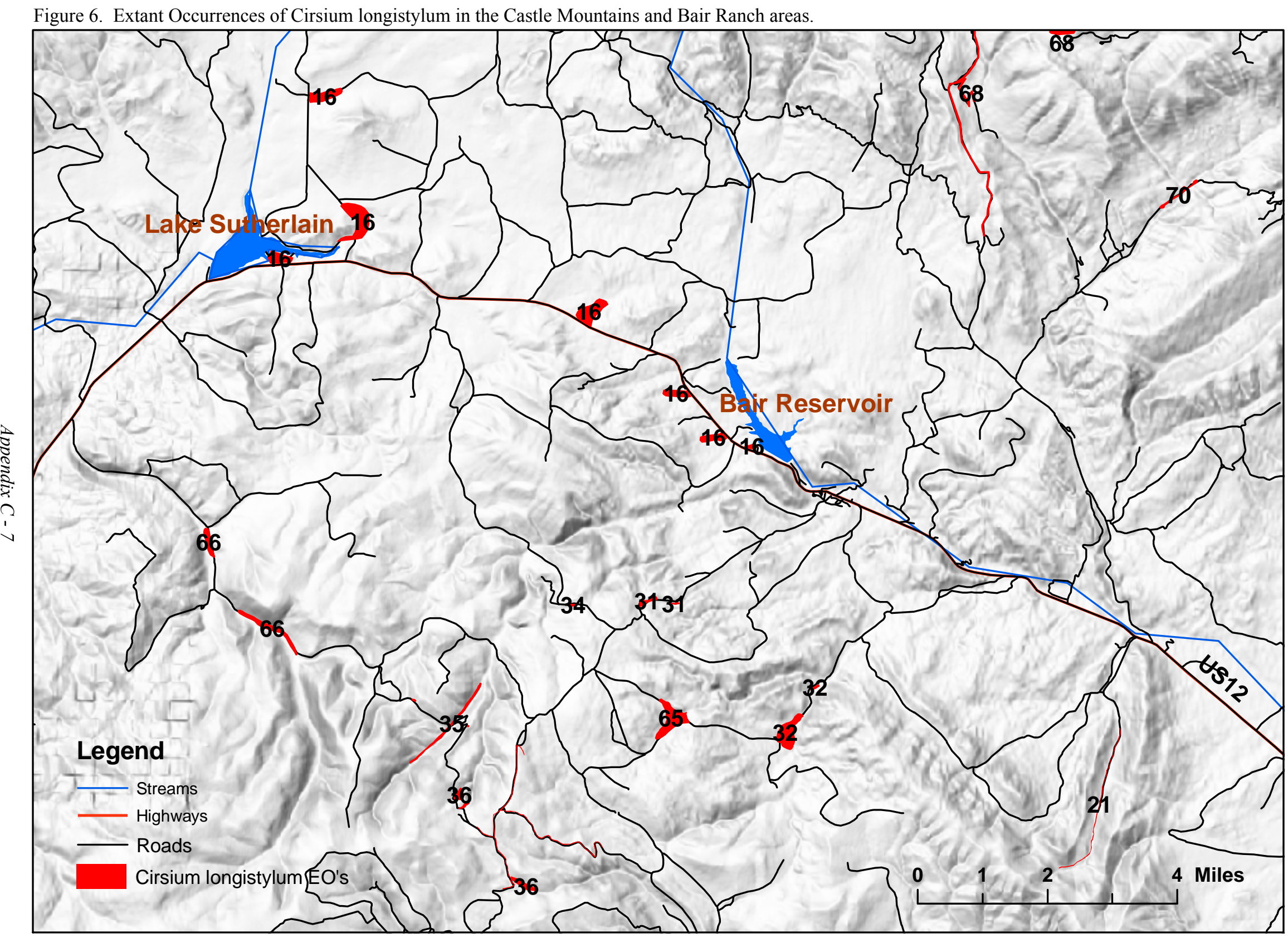


Figure 7. Extant Occurrences of Cirsium longistylum in the eastern Little Belts.

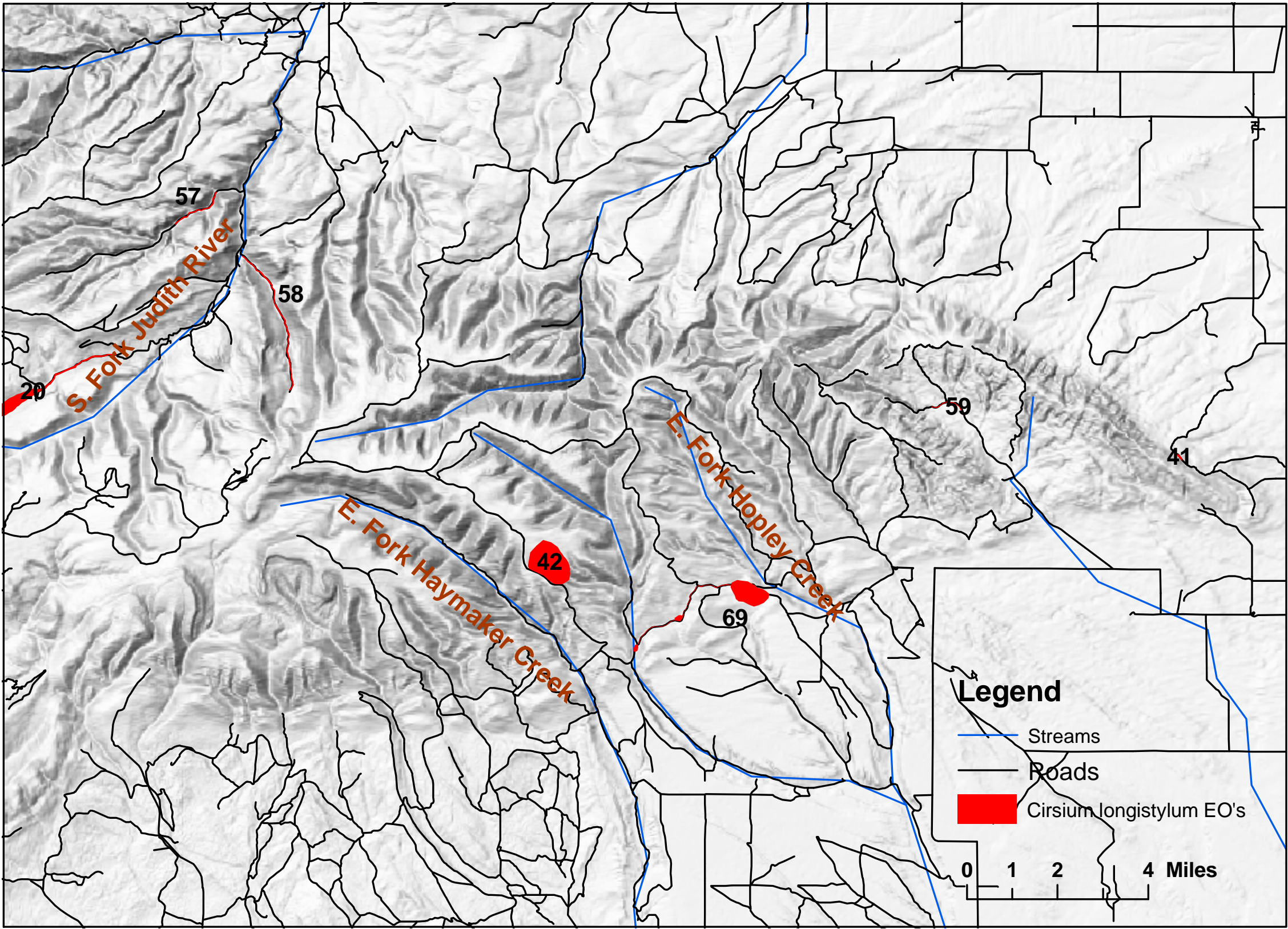

